\title{
Auditors and fiscal policy: Empirical evidence on a little big institution
}

\author{
Mark Schelker ${ }^{\mathrm{a}, \mathrm{c}, *}$, Reiner Eichenberger ${ }^{\mathrm{b}, \mathrm{c}}$ \\ a SIAW-HSG, University of St. Gallen, Bodanstrasse 8, CH-9000 St. Gallen, Switzerland \\ ${ }^{\mathrm{b}}$ Center for Public Finance, University of Fribourg, Pérolles 90, CH-1700 Fribourg, Switzerland \\ ${ }^{\mathrm{c}}$ Center of Research in Economics, Management and the Arts (CREMA), Gellertstrasse 18, CH-4052 Basel, Switzerland
}

\section{A R T I C L E I N F O}

\section{Article history:}

Received 12 November 2008

Revised 7 September 2010

Available online 21 September 2010

\section{JEL classification:}

D70

H10

Keywords:

Public auditor

Audit court

Auditing

Transparency

Information asymmetry

\begin{abstract}
A B S T R A C T
Schelker, Mark, and Eichenberger, Reiner-Auditors and fiscal policy: Empirical evidence on a little big institution

Various political institutions designed to control the government have been analyzed in the academic literature. However, an important institution has been neglected so far: independent auditing institutions with an extended mandate to audit the budget draft and individual policy proposals. We argue that such auditors improve transparency and provide essential information on the impact of policy proposals on common pool resources, which leads to less wasteful spending. We empirically analyze the impact of such auditors on fiscal policy at the Swiss local level. Auditors who can evaluate and criticize policy proposals ex ante to policy decisions, significantly reduce the general tax burden and public expenditures. The results are similar for different datasets and robust to various changes in the econometric specification. Journal of Comparative Economics 38 (4) (2010) 357-380. SIAW-HSG, University of St. Gallen, Bodanstrasse 8, CH-9000 St. Gallen, Switzerland; Center for Public Finance, University of Fribourg, Pérolles 90, CH-1700 Fribourg, Switzerland; Center of Research in Economics, Management and the Arts (CREMA), Gellertstrasse 18, CH-4052 Basel, Switzerland.

( 2010 Association for Comparative Economic Studies Published by Elsevier Inc. All rights reserved.
\end{abstract}

\section{Introduction}

In mature democracies, fundamental rules such as the separation of powers and regular elections have been established. Nevertheless 'pork barrel' and special interest group politics are well documented phenomena that often lead to the overuse of common pool resources. Even though various institutional mechanisms to mitigate these problems have been discussed, an important institution has been widely neglected so far: independent public auditing institutions.

Traditional auditors typically analyze the financial statements provided by the government and evaluate the use of public funds. All developed democracies feature some form of supreme auditing institution. Usually, these audit offices are fairly large: the German Bundesrechnungshof and its associated offices employ more than 1300 individuals and the US Government Accountability Office (GAO) counts more than 3000 employees and has a budget of more than 500 million USD. These auditors typically conduct ex post audits which target bookkeeping procedures and the effectiveness of policy implementation. Hence, they are carried out after decisions have been made in the political process and the budget or specific policies have been implemented. These ex post audits provide information on public governance and the use of public resources and are an important means of holding public officials accountable.

\footnotetext{
* Corresponding author. Address: Swiss Institute for International Economics and Applied Economic Research (SIAW), University of St. Gallen, Bodanstrasse 8, CH-9000 St. Gallen, Switzerland.

E-mail address: mark.schelker@unisg.ch (M. Schelker).
} 
In contrast to what is audited in ex post audits, most budgetary 'tricks' are adopted ex ante to decisions and are, hence, not subject to a typical auditor's evaluation. We argue that the standard ex post mandate of public auditing institutions should be complemented by a set of ex ante audit measures. Ex ante audits are not typically conducted by existing public auditing institutions. We present evidence that the ex ante and ex post auditing mandates of public auditing institutions have an important impact on policy outcomes. In addition to the standard ex post audit of the accounts and the performance of policy programs, auditors should analyze the fundamentals of the budget draft and evaluate individual policy proposals. The additional information provided by such a powerful auditing institution strengthens common pool interests, improves transparency, and reduces the overuse of common pool resources.

We test our hypotheses by analyzing a unique institutional setting in Switzerland where some local auditing institutions are actively involved during the policy making process. They not only evaluate programs ex post to the implementation, but also evaluate policy proposals ex ante to the political decision and report their findings to the public. Some auditors are even allowed to make counter-proposals, which are then put to the public vote. We construct a measure capturing the relevant aspects of the design of local auditing institutions and provide empirical evidence highlighting the importance of such powerful auditors.

The institutional designs of local auditing institutions are homogenous within cantons but vary substantially across cantons. This is the variance we rely on in the empirical exercise. We estimate the influence of local auditing institutions on fiscal variables such as public expenditures and taxes relying on municipal data as well as on municipal information aggregated at the cantonal level. We always control for institutional differences across cantons, e.g., the extent of local and cantonal direct democracy as well as the degree of decentralization measured by the extent of local autonomy. The study has to rely on cross-sectional variance since - almost by definition - institutions do not frequently change over time. We consistently find a strong negative and significant correlation between the power of local auditors and the level of taxes and expenditures. Even though we cannot present persuasive instrumental variable regressions, we address potential endogeneity problems from various perspectives: we take account of a wide range of control variables including measures of fiscal preferences that might drive the institutional design as well as fiscal outcomes simultaneously, and we formulate differential hypotheses based on our theoretical arguments that make it unlikely that some omitted factors drive our results in such a subtle way. We conclude that powerful auditors have a significant negative effect on taxes and expenditures.

In Section 2 we provide the main arguments for extending auditing competences beyond traditional ex post audits to include substantial ex ante audits. We discuss some important aspects of the institutional design for such a new type of auditing institution and formulate testable hypotheses. Section 3 introduces the test case in Switzerland and provides information on the institutional design of local auditors and the codification of the index capturing the auditor mandate. The presentation of the datasets and a discussion of the empirical identification strategy including our various approaches to deal with potential endogeneity follow in Section 4. In Section 5 we present our empirical results. Section 6 summarizes and concludes.

\section{The (potential) role of auditors in the public sector}

Democratic governance requires the delegation of decision-making power to agents. The resulting agency problem between citizens and government agents is well established. Because citizens do not have perfect control over, and lack information about, the agents' actions, institutional safeguards are necessary in order to restrain the government from exploiting its citizens. Conditional on the underlying political regime and its institutions, public finance outcomes differ. ${ }^{1}$ In the last decade a wide range of political regimes and institutional arrangements have been analyzed. ${ }^{2}$ This work builds upon these foundations and focuses on an institution directly influencing information cost and information asymmetry in the policy process.

The result of market interactions depends on the transaction rules and transaction costs present in such interactions. An important part of transaction costs is the cost to generate and analyze information. Institutions and rules fostering higher transparency tend to lower information costs and information asymmetries, and thus to improve market outcomes. Policy making in political markets also involves information cost and information asymmetries. Policymakers as well as citizens need information to make policy and electoral decisions, respectively. In the presence of significant information cost and information asymmetries political markets produce suboptimal results. ${ }^{3}$ In order to reduce such information problems in the democratic decision-making process, various political institutions have been established. One major factor is transparency requirements mandating information disclosure as well as the subsequent review of such disclosed information (e.g., Alt and Lassen, 2006). In this paper we focus on the second aspect, the review of disclosed information, and argue that such review is relevant at two instances in the political process. (1) When basic information is revealed that constitutes the fundamentals for policy decisions, and (2) when policies are implemented and the final information on policy outcome has to be verified. Typically, only the second aspect is regularly and systematically conducted by public auditing institutions.

\footnotetext{
1 See e.g., Person et al. (1997, 2000) or more generally Acemoglu (2003).

2 For an overview of the field, theoretical approaches and specific institutions see Persson and Tabellini (2000), Mueller (2003) or Besley and Case (2003), for institutions specific to Switzerland see Feld and Matsusaka (2003), Feld et al. (2003), Funk and Gathmann (2008) and Schaltegger and Feld (2009).

3 See e.g., Lohmann 1998; Besley (2006); Eichenberger and Serna (1996).
} 


\subsection{Auditors' impact on public finance}

Public auditing institutions aim to reduce information costs and the agency problem between citizens and the government by reviewing financial information. Such independent review of financial statements is important because the disclosure requirements of financial information are only effective if the information provided is accurate and timely (see Schelker, 2008). Standard public auditing institutions analyze financial statements and evaluate government performance in order to improve transparency and reduce information asymmetries between citizens and their government. From this perspective, we draw our attention to theoretical arguments tied to the role of information in the policy process, where an important related line of research focuses on the impact of budgetary transparency on fiscal outcomes (e.g., von Hagen, 1992, Alesina and Perotti, 1996; Ferejohn, 1999; Milesi-Ferretti, 2004, and Alt and Lassen, 2006).

Conventional auditing institutions typically conduct ex post audits of the financial statements and evaluate bookkeeping procedures for accuracy and accordance with accounting rules and regulations. Some also conduct ex post evaluations of programs and policy implementation, i.e. performance audits. Recent contributions analyzing the impact of independent ex post financial audits on wasteful spending and corruption (e.g., Olken, 2007; Ferraz and Finan, 2008), and the influence of ex post performance audits on various measures of government performance (Schelker, 2008) suggest that these audits have favorable effects on the workings of government, since they reduce information cost and information asymmetries. However, ex post audits cannot evaluate information on the basic allocation of public funds, since the audits are conducted after the decisions in the policy process have been made and after the resources have been spent. Consequently, the traditional perspective on auditors is confined to the ex post control of government agents and does not address the allocation of public funds in the policy making process. In other words, the specific information in the budget draft and policy proposals cannot be scrutinized by an independent auditing institution.

However, there is ample evidence that the fundamental information underlying the budgetary draft (e.g., revenue, growth, or inflation forecasts) can be manipulated (e.g., Alesina and Perotti, 1996; Milesi-Ferretti, 2004; Wallack, 2007; Bernoth and Wolff, 2008). Similarly, the cornerstones of individual policy projects are easily influenced. Examples are cost and revenue estimates, the forecasts of future demand for, and the necessary capacity of public infrastructure such as highways, railways, and tunnels, depreciation rates, maintenance costs, etc. Hence, the reported details of individual policy propositions might not accurately reflect the necessity of the project and its actual impact on public funds, the common pool resources. This fundamental information is prone to bias and, at the same time, individual voters and policymakers often have no or only weak incentives to invest in careful analyses of the budget draft and new proposals.

Obviously, biased information might only translate into biased policy if we assume that information is essential for policy decisions, is not freely available and costly to acquire. As long as all affected interests are equally organized and represented in the political process biased information must not necessarily result in biased policy decision. If biased information affects interest groups negatively, they have incentives to invest in the acquisition of information and take action against biased policy propositions. However, if there are interests that are systematically un- or under-represented, biased information results in biased policy decisions.

Consider the difference between large and small interest groups. Relatively small special interests are often able to overcome the collective action problem ${ }^{4}$ and become organized. Hence, they can inform policymakers about their preferred policies. In contrast, large groups with broad interests - such as efficiency oriented common pool interest (e.g., taxpayers) - often fail to overcome the collective action problem and cannot articulate in the policy process. A direct implication of this organization asymmetry is that the unorganized cannot invest in careful analysis and fail to take action against biased information in the decision-making process.

According to the fiscal commons argument ${ }^{5}$ special interest groups tend to formulate policies that do not internalize the full cost because the benefits of these policies target a narrow group while the costs are spread over all of society. Hence, policy propositions that benefit specific groups but are financed out of the common pool tend to be sub-optimally large. ${ }^{6}$ As argued above these projects are typically not critically evaluated and hence, the information relevant for decisions remains biased. ${ }^{7}$

Independent auditors could fill this gap by ex ante auditing and evaluating the fundamental economic assumptions and financial implications underlying the budget draft and individual policy projects. The freely accessible information from such audits could substantially reduce the information asymmetry, and improve transparency and the quality of information relevant for policy decisions.

\footnotetext{
${ }^{4}$ See Olson (1965), and e.g., Lohmann (1998). For the influence of information in the policy process and the influence of organized interest groups see also Grossman and Helpman (2001).

5 See the fiscal commons argument by Buchanan and Tullock (1962), and further developed by Weingast et al. (1981) and von Hagen and Harden (1995) in which beneficiaries of a certain policy do not internalize the full cost of such policies because they are financed out of the common pool. E.g., von Hagen and Harden (1995) specifically focus on the difference between spending ministers targeting their spending towards a specific constituency, and the Minister of Finance, who is assumed to give more weight to the collective interest of the government. Hence, spending ministers tend to favor higher than optimal government spending.

${ }^{6}$ Note, that since our test case will be at Swiss local level we do not analyze the size of the legislature at the cantonal level and do not primarily focus on the law of $1 / n$. But we emphasize this mechanism when testing our second hypothesis focusing on the interaction of the auditing mandate with the population size in municipalities with town meeting, in which the citizens themselves constitute the legislative body. For evidence on the fiscal commons problem at the cantonal level in Switzerland see Schaltegger and Feld (2009).

${ }^{7}$ The traditional fiscal commons argument (e.g., Weingast et al., 1981) does not require information asymmetry to arise. Overspending can also occur if all agents fully observe the benefits and costs of public expenditure.
} 


\subsection{Auditors' incentives to provide accurate information}

So far we assumed that the auditing institution actually reveals essential and accurate information. Obviously, we need to ask why auditors are not captured by, and do not collude with, special interests. In this section we briefly outline some mechanisms which help keep the auditors independent and committed to their task.

First, auditors need to have a clearly defined mission to assess the budget and policy propositions from a financial perspective and to transmit the auditing results to the principal. A clearly defined mission makes it easier to observe and evaluate an auditor's performance, which is essential in order to hold them accountable (for a general discussion of the role of missions, see e.g., Dewatripont et al., 1999).

Secondly, auditors should neither have voting rights, any authority to introduce sanctions nor co-decision rights. This prevents auditors from directly engaging in log-rolling and restricts their influence in the decision-making process to consulting, more specifically the production of information. Hence, auditors are, compared to traditional policymakers, less attractive targets for lobbyists and the opportunities to extract office rents are much smaller.

Thirdly, auditors have to be given incentives to cater to common pool interests. The direct election of public officials enhances their accountability to the general electorate (Frey, 1994; Besley and Coate, 2003, and more generally Persson et al., 1997). This is especially important since auditors with an extended ex ante auditing mandate might be in conflict with interests of members of the legislative and the executive. Therefore, auditors may not be appointed by the agents it ought to supervise, but directly by the principal, the citizens and taxpayers of the entire jurisdiction who collectively have an interest in sound financial analysis. ${ }^{8}$ If we assume that citizens not only share special interests with a specific group of individuals, but also share a general interest in sound public finance with all other taxpayers then the separate election of auditors and policymakers makes it possible for voters to unbundle their special interests from the more general common pool interests. Moreover, if auditors are directly elected, electoral rules must be considered. In order that auditors pursue common pool interests and focus on allocative efficiency rather than on specific interests and redistribution, they have to be elected in majority votes in a single jurisdiction-wide district. Then they must seek support from the entire jurisdiction, which ensures broad-based interest representation. ${ }^{9}$

Fourthly, it appears that opposition parties may have similar incentives to provide information. However, they are also bound by special interests and more interestingly they have strong incentives to pursue obstructive rather than constructive strategies for two reasons: first, political outcomes are attributed to the government rather than to the opposition parties. Second, opposition parties that choose constructive strategies run the risk that voters like their influence and thus, do not elect them into government but rather want to keep them in this fruitful opposition role. Hence, taking a constructive position may worsen the electoral prospects of an opposition party. In contrast, members of the auditing office do not compete to be elected into government. They can boost their chances to be re-elected as auditors by pursuing constructive strategies and trying to provide new and essential information to the public and its representatives.

\subsection{Hypotheses}

Based on our previous discussion we can formulate hypotheses. If auditors dispose of an encompassing auditing mandate including standard ex post audits (i.e. ex post evaluations of the accounts as well as implemented policies) and ex ante audits (i.e. ex ante evaluations of the budget draft as well as individual policy projects), transparency improves in two dimensions: (1) ex ante audits reveal information on the fundamentals of the budget draft as well as on the financial and fiscal impact of proposed policies, which would otherwise not be provided systematically and (2) ex post audits help to hold policymakers accountable for their policy implementation. Both reduce information cost and information asymmetries, which should in turn reduce the overuse of common pool resources. Hence:

Hypothesis 1. A more extensive auditing mandate including a full set of ex ante and ex post auditing competences is to (cet. par.) reduce general expenditures and taxes.

In a regression framework we estimate the following general specification and expect the estimated effect of auditors $(\beta)$ to result in a negative coefficient.

$$
y=\alpha+\beta A U D I T O R+\delta \boldsymbol{I}+\lambda \boldsymbol{X}+\varepsilon,
$$

where $y$ is a variable reflecting fiscal outcome such as e.g., government expenditures, or taxes, and AUDITOR is a variable capturing the auditor mandate and involvement in the policy process. Furthermore, $\boldsymbol{\delta}$ and $\boldsymbol{\lambda}$ are parameter vectors, $\boldsymbol{I}$ is a matrix reflecting additional institutional features influencing the decision-making process, $\boldsymbol{X}$ is a matrix including important crosssection characteristics, and $\varepsilon$ is the error term.

\footnotetext{
${ }^{8}$ For a more detailed discussion of the relevant literature and empirical evidence for the case of regular auditing institutions see Schelker (2008, 2010). The empirical analysis of the selection mechanisms of US State Auditors suggests that auditors with more substantial (ex post) auditing competences should be directly elected rather than appointed. In our setting auditors are endowed with an even broader set of tasks and competences including ex ante audits, which makes direct election even more important. For a general discussions of whether public officials should be appointed or elected see e.g., Ferejohn (1999), Besley and Coate (2003), and Maskin and Tirole (2004).

${ }^{9}$ More on electoral rules and district size see e.g., Baqir (2002), Milesi-Ferretti et al. (2001), or Persson and Tabellini (2004).
} 
Our theoretical arguments make it possible to derive a differential hypothesis. This is especially important since this helps to corroborate our theoretical considerations and attenuate possible concerns relating to endogeneity. Since free-rider and collective action problems become more pronounced with increasing group size, we expect the organization difficulty of common pool interests and hence, the resulting information problem to be more pronounced in larger relative to smaller jurisdictions. This leads us to formulate our next hypothesis.

Hypothesis 2. The influence of an encompassing auditing mandate is to (cet. par.) be stronger in larger relative to smaller jurisdictions.

Thus, we estimate a specification including an interaction term between the population size of a jurisdiction and the auditor variable. We expect both $\beta$ and $\gamma$ to be negative.

$$
y=\alpha+\beta A U D I T O R+\lambda(\text { POPULATIONSIZE } * \text { AUDITOR })+\delta \boldsymbol{I}+\lambda \boldsymbol{X}+\varepsilon
$$

We test these hypotheses empirically with data at the Swiss local level, where in some jurisdictions auditors have encompassing ex post and ex ante auditing mandates.

\section{Auditors in Switzerland}

\subsection{The Swiss research laboratory}

Switzerland and the United States share some important institutional characteristics that make them well suited for empirical research for at least two reasons: (1) Both exhibit highly decentralized government structures, with different government levels enjoying a high degree of autonomy. The Swiss federal structure consists of three hierarchical government layers: the federal government (the Confederation), the 26 Cantons (the States) and the 2880 municipalities, which all enjoy a high degree of autonomy and independently make a wide range of political decisions (Ladner 1994; Feld et al., 2003). Therefore, we observe considerable variation in the institutional design across jurisdictions. (2) A further important element of the US and (even more pronounced) the Swiss government structures is that citizens enjoy various direct democratic participation rights such as different forms of referenda and initiatives. Note that not all cantons feature the same participation rights (Stutzer 1999; Feld and Kirchgässner, 2001; Feld and Matsusaka 2003). These direct democratic rights are an important characteristic because they allow the evolution of institutions that more effectively control representatives. In contrast, policymakers themselves have typically no incentives to implement institutions that effectively restrict their own scope of action. The decentralized structure makes policy and institutional experiments in a common (e.g., national) framework possible, while direct democratic rights enhance the probability for creating new institutions, but at the same time provides an effective mechanism to abort failed experiments. These and other institutional features make the Swiss example an attractive laboratory to conduct empirical research. Of course, cross-country research often features much more institutional variation. However, the common national institutional framework substantially reduces the problem of unobserved heterogeneity, and thus, diminishes omitted variable bias (see also Besley and Case, 2003).

In Switzerland, municipal revenue and expenditure almost equal the shares of the federal government. All three government layers primarily finance their needs with their own taxes and user charges. The cantons as well as the municipalities rely heavily on direct taxes (around 95\% of total tax revenue), whereas the federal government relies much more on indirect taxes (around 60\% of total federal tax revenue) such as the VAT. The cantons and the municipalities levy the major part of direct income taxes, although the federal government also raises its own (highly progressive) income tax. The extent of the total income tax burden (including cantonal, municipal, and church taxes) varies considerably across cantons.

\subsection{Local auditors in Switzerland}

The Swiss institutional setting makes it possible to study the impact of auditors with an extended auditing mandate. Independent local auditors, the local finance commissions, ${ }^{10}$ exist in all municipalities with town meetings. ${ }^{11}$ Note that more than $50 \%$ of the total Swiss population live in such municipalities. In this setting citizens elect the government as well as an audit body, the finance commission. In the town meetings the government presents its policy proposals for the following period, while the auditors may analyze the government proposals and may be permitted to provide information and present counter-proposals.

The cantonal legislation on municipalities defines the basic institutional design of these auditors, but still leaves the municipalities some autonomy in the de facto design. However, while the intra-cantonal differences are very small, the in-

\footnotetext{
10 Depending on the canton, the finance commissions are known as 'Rechnungsprüfungskommission', 'Geschäftsprüfungskommission', 'Finanzkommission', or 'Commission des finances'.

${ }^{11}$ We only consider communities with town meetings, because only in this institutional setting is the auditor really independent. In parliamentary systems the finance commission is an ordinary legislative committee (e.g., Weingast and Marshall 1988 or Shepsle and Weingast 1994), an exception being some larger Swiss cities. In e.g., Zug and Olten (both featuring parliaments) the finance commission is an independent and directly elected body. However, these units only conduct the ex post audit of the accounts, similar to regular audit courts and cannot conduct any ex ante audits.
} 
ter-cantonal variation is large. ${ }^{12}$ In some cantons the auditors can only audit the accounts and similarly to an audit court, criticize the government at the end of a fiscal year (ex post). In other cantons, however, auditors are involved during the actual policy making process and have encompassing ex ante auditing competences as well as proposal and amendment rights. In addition to the standard ex post audit of the accounts, they can ex ante evaluate the budget proposal, individual investment projects, as well as the income tax rate and all other sources of income. To transmit the resulting information from the auditing process, auditors compile a report with the results of their analysis, announce their recommendation whether to support or to oppose the government proposal, and some are even allowed to advance amendments and alternative proposals. Subsequently, citizens choose in a majority vote between the status quo and the different proposals and delegate the policy implementation to the government.

All local auditors are directly elected by the citizens in a jurisdiction-wide district. The office has a clear mandate that is specified by local and cantonal laws and regulations, and it requires specific auditing skills. Hence, we often find auditing or accounting professionals in the audit office. Compared to a mandate in an executive position, the auditing mandate is less time consuming, and professional auditing knowhow can be transferred from the private sector to political office quite easily. Auditors are not usually career politicians, serve only as auditor, and do not subsequently run for an executive office. Local auditors have neither voting rights nor the power to implement their own proposals and, hence, they do not exercise any direct influence on the political outcome. These features are important in order to keep the audit office independent from other political offices.

It is essential to identify whether local auditors tend to be captured by special interests or not. From our many discussions with municipal auditors and experts from cantonal authorities responsible for monitoring the municipalities and from our survey evidence of the canton of Zurich, we are confident that auditor independence is strong and the selection of individuals in the finance commissions is different from regular political offices..$^{13}$ The available evidence points towards a different selection of the members of the local finance commissions. While financial expertise is important for members in the local audit offices, the traditionally strong local interest groups such as farmers and local business representatives are relatively under-represented in municipal finance commissions.

In contrast to the local auditing institutions there is no significant variation in the institutional design of cantonal auditing institutions called "Kantonale Finanzkontrolle". These cantonal auditing institutions are homogenous with respect to their independence as well as the mandate. While they belong to the cantonal bureaucracy and are formally subordinate to the executive branch - typically the cantonal minister of finance - they are also closely tied to the parliamentary audit and finance commissions. They conduct internal audits mostly relevant for the executive branch as well as external audits relevant for the legislative oversight. ${ }^{14}$

\section{3. 'Quantifying' auditor influence: the finance commission index}

To measure the scope of the auditing mandate we constructed an index that captures the institutional design of the local finance commission for the 26 cantons. The intra-cantonal design is relatively homogenous, whereas the inter-cantonal variation is important. In order to identify the de facto design, we first analyzed the (de jure) cantonal legislation on municipalities; then we investigated whether the municipalities made de facto use of the opportunities offered by cantonal law (see Schelker, 2008 and Schelker and Eichenberger, 2003). In summary, auditors may have the following competences and proposal rights:

1. Auditing competences.

- Ex post audit of the accounts.

- Ex post audit of individual projects.

- Ex ante audit and evaluation of the budget proposal.

- Ex ante audit and evaluation of individual projects.

2. Proposal rights (directly to the citizens).

- Recommendation with respect to the government proposition (acceptance/rejection).

- Right to advance alternative propositions.

\footnotetext{
12 Even though cantons frequently leave some autonomy in the de facto design to the municipalities, they often provide some general (non-binding) guidelines on how to organize the local auditing commission. Therefore, we observe extensive homogeneity across municipalities in a canton. However, one canton, the Canton of Zurich, shows at least some variation across municipalities. We have conducted a systematic survey of all municipal auditors in that canton. Descriptive statistics and some initial results from this dataset (Megert 2006), point in the same direction as the empirical evidence provided in the subsequent sections.

${ }^{13}$ For an overview of some more systematic evidence on the Canton of Zurich, see Megert (2006) who conducted a survey of local auditors in the Canton of Zurich. The Canton of Zurich is a good example, because most finance commissions are involved during the policy process and they are endowed with substantial ex ante auditing rights. A brief summary of the relevant insights can be found in Schelker (2008).

${ }^{14}$ This situation has changed in the last few years. However, all reforms started only after the time period analyzed in this paper. All cantonal auditing institutions became formally independent from the executive and the legislative branch. The cantonal reforms were based on a model-type statute that was taken over by all cantons over a few years. The cantons of Geneva and Vaud even went further to take over the model of court of accounts. With this reform these cantons installed courts of account ("Cour des Comptes") which conduct the external audits as well as an internal audit office ("Inspection Cantonal des Finances") subordinate to the executive branch. However, all audits remain of the ex post type.
} 
The auditing competences define the item to be audited and when the audit takes place (before or after implementation). The "Ex post audit of the accounts" is the regular audit procedure in which the auditor examines the reliability of the accounts and their compliance with general accounting standards. In the "Ex post audit of individual projects" the auditor analyzes individual projects by evaluating the effectiveness of its implementation and identifying any misuse of public funds. In the "Ex ante audit and evaluation of budget proposal" the auditor evaluates the budget proposal's compliance with accounting standards and evaluates the soundness of the budget proposal and if it is appropriate to the financial situation of the jurisdiction. In the "Ex ante audit and evaluation of individual projects" the commission evaluates individual investment projects before they are adopted and implemented. In order to effectively bring the extracted information into the political process, auditors may have recommendation and amendment rights.

We code each aspect with 1 (available) or 0 (not available) and aggregate them to the "finance commission index". We exclude "Ex post audit of the accounts" and "Recommendation with respect to the government proposition (acceptance/ rejection)" from our index because all auditors feature these competences (for details see Table A1 of Appendix A, or Eichenberger and Schelker, 2007). The variable was constructed for the period between 1990 and 2000. Since the variable is a de facto indicator we were not able to obtain reliable information from an earlier period. In a few cantons the finance commissions have been reformed after the time period under consideration. However, most reforms did not target the dimensions discussed in this study. The few reforms typically allowed that the ex post audits of the accounts can be outsourced to a professional accounting firm.

\section{Data and empirical strategy}

As a consequence of the extensive decentralization of Switzerland, the cantons are responsible for the collection of most of the data used in this study. Unfortunately, not all cantons use the same criteria and rules. Moreover, cantons as well as the federal administration do not provide fiscal data at the municipal level and comparable data is only available as an aggregate of cantonal and municipal fiscal measures at the cantonal but not at the municipal level. The only exception is personal income tax rates which is available at the local level and includes the tax burden from local and cantonal taxation. It is crucial to note, that not all cantons grant their municipalities the same fiscal autonomy and the allocation of competences and responsibilities between cantons and their municipalities are not identical. Hence, there is a substitution effect among municipal and cantonal spending and taxation (see Eichenberger 1994; Schaltegger 2001). Therefore, e.g., low municipal spending might just reflect heavily restricted competences and not particularly efficient governance. This makes it essential to analyze data including both government levels simultaneously. ${ }^{15}$

Since not all desirable information is available at the municipal level, we analyze two different datasets each including cantonal and local level data, but one aggregated at the municipal, and one aggregated at the cantonal level. Focusing on the municipal dataset we can test Hypothesis 1 by estimating the influence of local auditors on income tax rates. We also disaggregate the auditor index and analyze the impact of the various sub-indices. Furthermore, we evaluate whether auditors with an extended mandate have a greater impact in larger municipalities in which the collective action problem is deemed to be more pronounced (Hypothesis 2). The dataset containing information aggregated at the cantonal level enables us to analyze the impact of auditors on additional dependent variables such as taxes, expenditures, revenues, and deficits (Hypothesis 1).

\subsection{Municipal data}

Our empirical analysis at the local level focuses on data for the aggregated cantonal and local income tax rate of a natural person, for which there is a dataset from the Swiss Federal Tax Administration. This dataset provides information on tax rates for the 730 largest Swiss municipalities. It not only includes the 130 largest Swiss cities for which a broad spectrum of fiscal information is available, but also a rich sample of smaller municipalities featuring town meetings. This tax data is the only systematic fiscal data available for a larger sample of Swiss municipalities. However, it is only available from 1997 for a smaller sample of municipalities. Since our analysis has to focus on the period from 1990 to 2000 and we do not observe any significant variation in the design of the auditing institution, we conduct a cross-section analysis for the year 1999.

\subsubsection{Dependent variable: tax rates}

The tax rate includes taxes of the canton, the municipality, and the local official church communities (which have the power to tax) on a natural person's annual income. The dataset contains 16 income brackets between CHF 20,000 and $1,000,000$ and three household types: "single, employed wage earner", "married, sole wage earner", and "married, sole wage earner with two children". We calculate the average tax rates across all income brackets between CHF 40,000 and 200,000 annual income and across the three household types. We focus on these income brackets, since the lowest and highest income brackets are only relevant for relatively few individuals and it is likely that they are not evenly distributed across

\footnotetext{
15 See also the empirical evidence by Funk and Gathmann 2005, 2008 on the influence of direct democracy on fiscal outcomes when this substitution effect is considered. Their results on direct democracy are very similar to the findings reported in this study.
} 
communities. However, estimations with the complete dataset controlling for the different income and household classes produce largely the same results.

\subsubsection{Explanatory variables}

The finance commission index described above capturing important aspects of the institutional design of local auditing institutions varies considerably across cantons, but the intra-cantonal design is fairly homogenous. The variable enters the dataset as the auditor variable and varies between 0 and 4 .

Other institutional features such as the extent of local and cantonal direct democratic rights or the degree of decentralization are important for studies on Switzerland. Therefore, we include different indicators for direct democratic instruments and fiscal decentralization in our empirical models. Direct democracy at the local level is captured by a dummy variable for town meeting (1) or parliamentary democracy (0). To specify the magnitude of direct democracy at the cantonal level we use an encompassing indicator of direct democracy subsuming not only financial referendums but also all relevant aspects of the extent of direct democratic instruments available to the citizens. This includes referenda on constitutional as well as statutory amendments, which, of course, also heavily influence spending decisions. A further advantage is that it includes signature requirements, which have been shown to be influential in a recent study by Funk and Gathmann (2008). Since we are not primarily interested in the specific effects of different direct democratic instruments we opt for the broad indicator of direct democracy which reflects all the different facets of direct democracy. Hence, we use the standard indicator proposed by Stutzer (1999) and Frey and Stutzer $(2000,2001) .{ }^{16}$ As a robustness test we also use a sub-index of the variable by Stutzer focusing only on the availability of a financial referendum as well as the often used dummy for the existence of a mandatory financial referendum at the cantonal level (Feld and Matsusaka, 2003). The choice of the direct democracy variable proofs not to be crucial for the purpose of our endeavor. None of these measures challenges our results for the impact of auditing institutions. Since the dummy variable on the existence of a mandatory financial referendum is - besides the index proposed by Stutzer (1999) - most often used in this kind of research, we report a series of robustness tests including the financial referendum dummy instead of the more complex index by Stutzer in Section 5.4. As can be seen from these tables, our results remain robust.

To map the degree of fiscal decentralization in a specific canton we introduce an index proposed by Ladner (1994), which captures the extent of local autonomy in each canton as reported by the local chief administrators in a systematic survey. The local chief administrators of 1856 municipalities reported on the perceived extent of local autonomy on a scale between 1 and 10. A score of 1 indicates 'no autonomy at all' and 10 'very high' degree of local autonomy. This index is widely used to measure local autonomy and to proxy fiscal decentralization in Switzerland (e.g., Frey and Stutzer, 2000, 2001, and Torgler, 2005). The advantage of such a measure is that it captures the de facto institutional constraints of a municipality. It reflects the federal structure of a canton, i.e. the division of competences between the canton and its municipalities (Frey and Stutzer, 2000). Other measures such as the ratio of municipal expenditures to total cantonal and local expenditures tend to be endogenous to the institutional framework and many other factors. However, as this ratio is one of the standard approaches for cross-country research and is also used in Switzerland (e.g., Schaltegger, 2001 and Feld et al., 2003), we also included it as an alternative measure.

To control for community-specific characteristics, which impact on public expenditures and taxes, we include a broad set of standard control variables such as the average municipal real per capita income, the population size, its demographic structure, the unemployment rate, and the fraction of foreign population. Furthermore, we also include topographic factors such as the surface of the municipality, its edificial, industrial, agricultural, and mountainous fraction, the level of education, political preferences as measured by party support in federal elections, and a dummy for language affiliation (German 1, else 0 ). The cultural background reflected by the language affiliation and the party support in federal elections serve as a proxy measure for fiscal preferences. Pujol and Weber (2003) and Funk and Gathmann (2005) showed that there is a systematic relationship between cultural affiliation and fiscal preferences.

To control for effects due to some specific income distribution (e.g., Meltzer and Richard, 1981) it would be useful to have data on the mean and median income or Gini-coefficients (pre- and after-tax). This data is, however, only available for the fiscal year 1995/1996 (Ecoplan, 2004). Even though the time periods do not perfectly match, we use the data as a further robustness check but did not find any effects challenging our results.

Of course, it would also be interesting to control for other political variables, such as the composition of local governments and government fractionalization, which have been found to be relevant in explaining fiscal policy in cross-country as well as in US cross-state regressions. However, for the Swiss local level, data on the composition of the governments is neither available nor would it be informative. Since most members of Swiss local governments are elected on a personal basis in majority votes they are often not members of an established political party. Moreover, it is difficult to compare political parties across cantons as even the cantonal sections of parties with nationwide activities already largely differ between cantons, e.g., evidenced in the fact that they often advance opposing recommendations for nationwide referenda. Therefore, we do not include measures for the political position as well as the composition of the local government to our estimates. Moreover, since our analysis is focused on municipalities with town meetings - in which the citizens themselves constitute the legislative body - there is no measure for party composition, the number of legislatures or legislative fractionalization at the municipal level. However, we include average party support in national elections per municipality for the main national

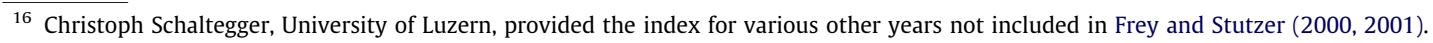


parties and we investigate the influence of the population size in combination with the auditing mandate of local auditors (Hypothesis 2), which could be interpreted as a version of the law of $1 / n$ in the context of municipalities with town meetings. Furthermore, we also try to control for local public goods provision. However, at the local level there is only sufficiently good data on the availability of public transportation. ${ }^{17}$

\subsection{Cantonal data}

At the cantonal level we assembled a dataset for the period between 1990 and 2000. As already mentioned we were not able to obtain reliable information about the de facto design of local auditing institutions prior to this period.

\subsubsection{Dependent variable: tax burden and government expenditures}

Reliable data exists for the aggregate of the local and cantonal tax burden as well as public expenditures, revenues, and deficits for each canton. The aggregated tax burden on natural persons is an index constructed by the Swiss Federal Statistical Office and includes the taxes levied by the canton, the municipality, and the local official church communities on a natural person's annual income. The data on aggregated local and cantonal per capita public expenditures and revenues include the cantonal government expenditures (revenues) and the aggregated government expenditures (revenues) from all municipalities in the same canton over a budgetary period and are provided by the Swiss Federal Tax Administration. Unfortunately, this data also includes federal grants, which are used to finance federal and trans-regional infrastructure projects. These vertical transfers appear in cantonal expenditures even though they are heavily co-financed by the federal government. In this respect the Canton of Uri is an outlier because a large share of its budget consists of such infrastructure projects. Excluding the Uri observations from our empirical analysis - a standard procedure in other studies - makes our results slightly stronger and more stable overall.

\subsubsection{Explanatory variables}

We already discussed the institutional variables we use to analyze municipal data. Most of them can also be employed for our analysis at the cantonal level. However, the dummy variable for local direct democracy must be refined. In this dataset at the cantonal level we use the fraction of the cantonal population living in municipalities with town meetings. Furthermore, our auditor measure must also be adapted. Because powerful, independent auditors only exist in municipalities with town meetings, we weight the finance commission index with the prevalence of town meetings in each canton. ${ }^{18}$

We include a standard set of control variables mostly identical to the covariates discussed for the municipal dataset. However, we have some additional variables reflecting various aspects of public goods provision. The dataset contains data on class size in primary school, traffic infrastructure (road length), rental prices, and conviction rates. Unfortunately, we could not identify stronger proxies because, e.g., school performance measures, etc. are not systematically available in Switzerland.

As a further step to reduce omitted variable bias, we include direct measures of fiscal preferences. Fiscal preferences might be important when analyzing fiscal institutions. They could be the driving force in establishing institutions and simultaneously also directly shaping the policy outcome. Not including such a measure could result in serious endogeneity problems, where the effect of institutions cannot be separated from fiscal preferences. It is only recently that Funk and Gathmann (2005) calculated measures of fiscal preferences by analyzing initiatives and referenda at the national level. Using factor analysis and a broad set of direct democratic policy decisions, they identify three factors that reflect different fiscal preference dimensions. They show that the influence of direct democracy is substantially reduced if fiscal preferences are taken into account.

For more information on the most important variables, descriptive statistics and correlations see Tables A2-A4 of the Appendix.

\subsection{Empirical strategy and endogeneity}

The municipal cross-section data provides information to test whether auditors with an extended auditing mandate have an influence on tax rates (Hypothesis 1) and if this impact varies depending on the size of a community (Hypothesis 2). We estimate the effects using ordinary least squares (OLS) and weighted least squares (WLS) estimators and adjust standard errors for clustering across cantons. Within the cantons, municipalities face similar constraints and the standard errors may be correlated within cantons. Therefore, we estimate cluster-robust variance estimators and correct according to the 26 cantonal clusters. Without clustering we may encounter downward bias of the standard errors (Moulton, 1986). Moreover, in the robustness section we present further estimates applying a more recent method to take within-group dependence into account when the number of clusters is small. With only few clusters, Cameron et al. (2008) show that standard errors computed by commonly used clustering procedures may still encounter downward bias since the asymptotic justification assumes that the number of clusters goes to infinity. They show that the wild cluster bootstrap-t procedure has favorable

\footnotetext{
17 In order to evaluate the effect of institutions on fiscal variables, controlling for public goods provision is important. It is a very challenging task to find good proxies for public goods provision and hence, most empirical studies do not even attempt to deal with this problem. We are aware that the proxies we use in the entire study are not perfect. However, we consider testing the robustness of our results with these imperfect measures to be an improvement.

${ }^{18}$ Not adjusting the auditor variable to the prevalence of town meetings does not substantially affect our results.
} 
properties even when the number of clusters is as low as 5. Table 9 presents a series of regressions showing the results when this alternative procedure is used to account for within-group dependence. This alternative method supports our findings.

To account for the possibility of non-random sampling, we estimate WLS models. We include sampling weights equal to the inverse of the probability of a municipality being included in the sample. This measure depends on the number of existing municipalities per canton, which drives the number of observations in our sample. It is possible that the probability of a municipality being included in the sample also depends on its population size. Therefore, we also calculated sampling weights that additionally adjust for the population size. The choice of weights does not qualitatively change our results. In the following discussion we will use the more common and also more conservative sampling weights depending on the number of municipalities per canton. We report a series of regressions using population adjusted weights in the section including various robustness tests (Table 7), which show that the results are not driven by the choice of the sampling weights.

The cantonal dataset assembles data between 1990 and 2000. Since we do not observe any significant variation of our institutional variables over time, we cannot control for time-invariant unobserved heterogeneity in a fixed effects (FE) framework. Thus, we estimate random effects (RE) models, which assume cross-section error components to result from a random draw and follow a normal distribution. We also estimate our data panel with a pooled OLS model, which is the standard method applied by most studies facing time invariant institutions. We consider the RE estimator to be our first reference and report langrangian multiplier tests. ${ }^{19}$ We further check the robustness of our results by estimating regressions on cantonal means and by applying fixed effects vector decomposition (Pluember and Troeger, 2007). The latter method relies on a three stage procedure where in the first stage, a model including cross-section fixed effects is estimated to obtain unit effects. In the second stage the unit effects are decomposed in a part which is explained by the time-invariant variables (auditors, direct democracy and federalism) and an error term. The third stage estimates the original panel model as pooled-OLS including timeinvariant variables and the error term from the second stage, which accounts for the unexplained part of the unit effects.

Obviously, there are serious concerns about the causal impact of auditors on fiscal variables. Our estimates could suffer from reverse causality, simultaneity, and omitted variable bias. Effective institutions are not necessarily exogenously given. Given the time persistence of our institutional variables, reverse causation seems not to be a great concern. However, simultaneity and omitted variable bias need to be addressed more carefully and we follow several strategies. First, as already mentioned we introduce a measure of fiscal preferences proposed by Funk and Gathmann (2005). If the auditing institution is only the result of specific fiscal preferences, which at the same time also shape political outcomes, then we could not make inference about the influence of local auditors. The inclusion of a fiscal preference measure in our empirical model should clarify this point. Secondly, we test a differential hypothesis (Hypotheses 2 ) which makes it less plausible that an unobserved factor drives the results so subtly. Thirdly, we employed instrumental variable (IV) techniques and ran two-stage least squares (2SLS) regressions (e.g., Wooldridge, 2002). However, finding valid instruments is an enormously difficult task, and we could not identify strong instruments which always complied with the required exclusion restrictions. The results of our IV approach can be found in the working paper version of this article (Schelker and Eichenberger, 2008).

\section{Empirical results}

\subsection{Hypothesis 1: auditors' influence on taxes and expenditures - municipal data}

Hypothesis 1 suggests a negative impact of stronger auditing mandates including a full set of ex ante and ex post audits on tax rates. Column 1 of Table 1 contains a simple OLS regression with standard errors adjusted for clustering. In this basic regression model we include the auditor variable, other institutional variables, local income, and the population measure. Column 2 presents the same basic regression introducing sampling weights and estimating WLS models. Columns 3-7 add groups of control variables to the basic regression model in column 2 . We first add the language variable as a proxy for fiscal preferences, and then include socio-demographic, topographic and economic variables, public goods and political proxies, and finally we estimate all covariates simultaneously.

The econometric results in Table 1 confirm Hypothesis 1 . The auditor variable exercises a highly significant negative impact on the aggregated cantonal and municipal tax rates. A one point increase of the auditor variable implies an average reduction of the income tax rate of roughly 0.45 percentage points. The results from the basic regressions are not sensitive to the inclusion of additional explanatory variables. The estimated coefficient remains stable and highly statistically significant. When estimating wild cluster bootstrap-t standard errors we find similar results. All estimated coefficients remain statistically significant at least at the $5 \%$ level (see Table 9). Since the auditor variable ranges from 0 to 4 a maximum potential reduction of roughly 1.8 percentage points is possible. Taking into account that the average tax rate amounts to roughly $11 \%$, the potential effect of the auditor design on the individual tax rate is about $16-17 \%$ lower if auditors are fully integrated during the policy process. Consequently, the effect of auditing institutions is not only statistically significant, but also economically highly relevant.

\footnotetext{
19 Besley and Case (2003) also discuss this problem and they present their results for the impact of voter initiatives (that do not vary significantly over time) on taxes and expenditures. They use OLS, RE, and regressions on state means. They report fairly large differences of the estimated coefficients when applying these methods, especially when analyzing government expenditures.
} 
Table 1

Hypothesis 1 - auditors and taxation (municipal data 1999).

\begin{tabular}{|c|c|c|c|c|c|c|c|}
\hline & $\begin{array}{l}(1) \\
\text { OLS }\end{array}$ & $\begin{array}{l}(2) \\
\text { WLS }\end{array}$ & $\begin{array}{l}\text { (3) } \\
\text { WLS }\end{array}$ & $\begin{array}{l}(4) \\
\text { WLS }\end{array}$ & $\begin{array}{l}(5) \\
\text { WLS }\end{array}$ & $\begin{array}{l}(6) \\
\text { WLS }\end{array}$ & $\begin{array}{l}(7) \\
\text { WLS }\end{array}$ \\
\hline Auditor & $\begin{array}{l}-0.604^{* * *} \\
(0.078)\end{array}$ & $\begin{array}{l}-0.483^{* * *} \\
(0.114)\end{array}$ & $\begin{array}{l}-0.493^{* * *} \\
(0.100)\end{array}$ & $\begin{array}{l}-0.441^{* * *} \\
(0.091)\end{array}$ & $\begin{array}{l}-0.492^{* * *} \\
(0.101)\end{array}$ & $\begin{array}{l}-0.461^{* * *} \\
(0.112)\end{array}$ & $\begin{array}{l}-0.435^{* * *} \\
(0.087)\end{array}$ \\
\hline Local direct democracy & $\begin{array}{l}1.261^{* * * *} \\
(0.248)\end{array}$ & $\begin{array}{l}1.349^{* * *} \\
(0.227)\end{array}$ & $\begin{array}{l}1.237^{* * *} \\
(0.251)\end{array}$ & $\begin{array}{l}0.954^{* * *} \\
(0.271)\end{array}$ & $\begin{array}{l}1.202^{* * *} \\
(0.198)\end{array}$ & $\begin{array}{l}1.360^{* * *} \\
(0.222)\end{array}$ & $\begin{array}{l}0.993^{* * *} \\
(0.271)\end{array}$ \\
\hline Cantonal direct democracy 1 & $\begin{array}{l}0.058 \\
(0.106)\end{array}$ & $\begin{array}{l}0.016 \\
(0.133)\end{array}$ & $\begin{array}{l}-0.064 \\
(0.142)\end{array}$ & $\begin{array}{l}-0.092 \\
(0.132)\end{array}$ & $\begin{array}{l}0.047 \\
(0.121)\end{array}$ & $\begin{array}{l}-0.020 \\
(0.117)\end{array}$ & $\begin{array}{l}-0.073 \\
(0.123)\end{array}$ \\
\hline Federalism & $\begin{array}{l}-1.213^{* * *} \\
(0.241)\end{array}$ & $\begin{array}{l}-1.150^{* * *} \\
(0.160)\end{array}$ & $\begin{array}{l}-1.165^{* * *} \\
(0.157)\end{array}$ & $\begin{array}{l}-1.247^{* * *} \\
(0.190)\end{array}$ & $\begin{array}{l}-1.179^{* * *} \\
(0.180)\end{array}$ & $\begin{array}{l}-1.156^{* * *} \\
(0.193)\end{array}$ & $\begin{array}{l}-1.167^{* * *} \\
(0.204)\end{array}$ \\
\hline Income & $\begin{array}{l}-0.080^{* * * *} \\
(0.012)\end{array}$ & $\begin{array}{l}-0.096^{* * *} \\
(0.015)\end{array}$ & $\begin{array}{l}-0.097^{* * * *} \\
(0.015)\end{array}$ & $\begin{array}{l}-0.066^{* *} \\
(0.025)\end{array}$ & $\begin{array}{l}-0.087^{* * *} \\
(0.014)\end{array}$ & $\begin{array}{l}-0.095^{* * * *} \\
(0.018)\end{array}$ & $\begin{array}{l}-0.065^{* *} \\
(0.023)\end{array}$ \\
\hline Population & $\begin{array}{l}1.59 \mathrm{e}-06 \\
(3.63 \mathrm{e}-06)\end{array}$ & $\begin{array}{l}4.01 \mathrm{e}-06 \\
(3.97 \mathrm{e}-06)\end{array}$ & $\begin{array}{l}2.97 e-06 \\
(3.53 e-06)\end{array}$ & $\begin{array}{l}5.69 \mathrm{e}-06 \\
(4.05 \mathrm{e}-06)\end{array}$ & $\begin{array}{l}8.11 e-06 \\
(4.96 e-06)\end{array}$ & $\begin{array}{l}2.94 \mathrm{e}-06 \\
(2.89 \mathrm{e}-06)\end{array}$ & $\begin{array}{l}2.92 \mathrm{e}-06 \\
(3.48 \mathrm{e}-06)\end{array}$ \\
\hline Language & & & $\begin{array}{l}0.382 \\
(0.274)\end{array}$ & & & & $\begin{array}{l}-0.185 \\
(0.284)\end{array}$ \\
\hline Young $(<24)$ & & & & $\begin{array}{l}5.523 \\
(3.749)\end{array}$ & & & $\begin{array}{l}6.412^{*} \\
(3.352)\end{array}$ \\
\hline Aged $(>65)$ & & & & $\begin{array}{l}5.851^{* * *} \\
(1.594)\end{array}$ & & & $\begin{array}{l}8.254^{* * *} \\
(1.786)\end{array}$ \\
\hline Unemployed & & & & $\begin{array}{l}-0.180 \\
(0.165)\end{array}$ & & & $\begin{array}{l}-0.130 \\
(0.147)\end{array}$ \\
\hline Tertiary education & & & & $\begin{array}{l}-0.018 \\
(0.019)\end{array}$ & & & $\begin{array}{l}-0.028^{*} \\
(0.014)\end{array}$ \\
\hline Foreigner & & & & $\begin{array}{l}-1.472^{* *} \\
(0.629)\end{array}$ & & & $\begin{array}{l}-1.166 \\
(0.715)\end{array}$ \\
\hline Population density & & & & & $\begin{array}{l}-0.008 \\
(0.006)\end{array}$ & & $\begin{array}{l}-0.005 \\
(0.006)\end{array}$ \\
\hline Mountain & & & & & $\begin{array}{l}1.908 \\
(1.299)\end{array}$ & & $\begin{array}{l}0.786 \\
(0.906)\end{array}$ \\
\hline Agriculture & & & & & $\begin{array}{l}1.083 \\
(0.648)\end{array}$ & & $\begin{array}{l}0.898^{*} \\
(0.436)\end{array}$ \\
\hline Industry & & & & & $\begin{array}{l}0.904 \\
(1.048)\end{array}$ & & $\begin{array}{l}0.725 \\
(1.181)\end{array}$ \\
\hline Public transportation & & & & & & $\begin{array}{l}-0.001 \\
(0.013)\end{array}$ & $\begin{array}{l}0.026^{* *} \\
(0.012)\end{array}$ \\
\hline Social democrats & & & & & & $\begin{array}{l}0.015 \\
(0.009)\end{array}$ & $\begin{array}{l}0.012 \\
(0.009)\end{array}$ \\
\hline Observations & 732 & 732 & 732 & 724 & 730 & 722 & 718 \\
\hline$R$-squared & 0.711 & 0.664 & 0.670 & 0.714 & 0.687 & 0.679 & 0.738 \\
\hline
\end{tabular}

Notes: Robust standard errors reported in parentheses, adjusted to clustering in 26 cantons. Dependent variable: Average aggregated tax rate including cantonal, local, and church taxes on a natural person's annual income, containing nine income classes between CHF 40 and 200,000 and three classes describing household characteristics: "single, employed wage earner", "married, sole wage earner", and "married, sole wage earner with two children". Constant term not reported. Sampling weights: Inverse probability of inclusion in sample (relative number of municipalities per canton).

Significance:

* $0.05<p<0.1$.

** $0.01<p<0.05$.

$* * * * 0.01$.

Local direct democracy in the form of town meetings exhibits a positive impact on tax rates. The coefficient is statistically significant, and its influence is with 1.1 fairly high. Ranging from 0 to 1 the potential effect is roughly $10 \%$ higher taxes. However, the potential effect of local direct democracy is still much smaller than the potential effect of the auditor variable. Cantonal direct democratic instruments do not significantly affect tax rates. The results also hold for alternative measures of direct democracy such as the dummy for cantons with a mandatory financial referendum (Feld and Matsusaka, 2003, reported in Section 5.4.) and the sub-index reflecting the right to a financial referendum by Frey and Stutzer (2000). The fact that the cantonal direct democracy variable does not have a significant influence on tax rates is not inconsistent with the existing evidence. First, most studies do not analyze the influence of direct democracy on taxes, but rather on expenditures and revenues. Secondly, most studies only focus on cantonal expenditures, which disregard systematic substitution effects between the local and cantonal level (Eichenberger, 1994; Schaltegger, 2001; Funk and Gathmann, 2005, 2008). Funk and Gathmann even show that cantonal direct democracy has different effects at the cantonal and the local level, which tend to cancel each other out. Thirdly, even though cantonal direct democracy exhibits no significant direct effect on taxes, it has still an indirect effect on fiscal outcomes. Feld et al. (2008) show that direct democratic instruments are an important instrument to maintain fiscal decentralization that proved to restrain the central government from accumulating more and more fiscal power. 
In line with the standard literature, fiscal decentralization exhibits a large negative and significant influence on tax rates. For every unit of increasing local autonomy, we estimate an average tax rate reduction of roughly 1.2 percentage points. Considering that the variable ranges from 3.2 to 6.1 we observe a potential effect of 3.5 percentage points, or up to $30 \%$ lower tax rates, which makes fiscal decentralization highly relevant. We provide a brief discussion and some interpretation of the overall effects of institutional variables at the end of the empirical section.

Local income has a strong negative impact on the tax rate, while the population measure does not reach statistical significance. Furthermore, our results are robust to the inclusion of a fiscal preferences proxy measure (language), which indicates that the influence of auditors is not endogenous to fiscal preferences (column 3). The additional socio-demographic variables basically confirm the expected results; however, their impact is frequently not statistically different from zero. The fraction of the population not included in the production process (old and young) both exhibit a tax increasing effect. Including further control variables such as the population density, the mountainous, agricultural and industrial area, or the fraction of votes for the social democrats (which could also be interpreted as a proxy measure for fiscal preferences), or the fraction of the population using public transportation to commute to work (public goods proxy) do not affect our results for the influence of local auditors on taxes. We also tested whether some specific income distribution affects our results and included the mean to median income ratio, even though the data is only available for the fiscal year 1995/1996. Our results are robust to the inclusion of all these measures.

Subsequently we only present the results of our main variables of interest and do not discuss the effect of control variables as long as the effects are similar to previous results. We restrict our discussion to additional or 'surprising' results.

\subsubsection{Disaggregating the auditor variable}

In order to better understand the influence of the different parts of the auditor variable we disaggregate the auditor index into its main components. Following our theoretical discussion the difference between ex post and ex ante auditing mandates seems most important. Totally disaggregating the index is not suitable because the sub-indices are not entirely independent from each other. For example, it would not make sense to endow the auditor with proposal rights during the policy process without endowing it with at least some auditing rights ex ante to policy decisions. Furthermore, it is also true that if an auditor can evaluate individual policy projects, it is also endowed with the right to analyze the budget proposal. Thus, the ex ante measures of our index are not entirely independent from each other. Therefore, we will mainly disaggregate the index into an ex post (dummy) and an ex ante (scale $0-2$ ) variable.

In Table 2 we present the results when disaggregating the auditor index and estimate the different components separately.

We find a significantly negative influence of ex post audits (dummy) in all estimated specifications. This indicates that auditing individual projects after implementation is negatively correlated with tax rates. The result is consistent with general findings for US auditing institutions that conduct ex post performance audits of policy programs (Schelker, 2008). The influence of ex post audits fostering transparency is not only statistically significant but also economically relevant. The estimated coefficient decreases when including the ex ante auditing variable. Otherwise, the estimates are robust to the inclusion of additional explanatory variables and changes in the specification, such as simple OLS estimation or the inclusion of different sampling weights.

The influence of ex ante audits (scale 0-2) also exhibits a statistically significant and robust negative influence. The coefficient of the ex ante variable also decreases in size when including the ex post auditing variable. Since the measure adds two dummy variables (budget proposals and individual project audits) and hence ranges from 0 to 2 , the potential effect results in around 9\% lower tax rates (columns 5 and 6), which is similar in magnitude to the potential impact of ex post audits (varying between 0 and 1 ).

Our estimates of the ex ante indicator including the proposal rights variable (scale 0-3) yield significant negative coefficients (columns 7 and 8). The measure ranges from 0 to 3 and exhibits a potential impact of a roughly $9 \%$ tax reduction. We find that the influence of proposal rights is weakest and does not have a significant effect on its own (estimates not reported). This is not entirely surprising because all finance commissions have to submit a report to the citizens. We observed that if auditors do not have a formal right to advance counterproposals, often a citizen close to a member of the finance commission proposes amendments. Furthermore, if the reports contain all relevant information and are easy accessible, the transaction costs for individual citizens to make proposals and amendments based on the audit report can be assumed to be relatively low. The magnitude of the combined effect of the ex post and the ex ante measures is, with roughly 1.8 percentage points (16\%) lower tax rates, similar to the estimates including the auditor index entirely.

If we include all four measures (individual projects ex post, budget proposals ex ante, individual projects ex ante, and proposal rights) separately we only find significant effects for the ex post measure and the ex ante audit of the budget proposal measure (not reported). The other measures do not attain statistical significance. This finding is not at all surprising because there is only one ex post variable, whereas there are three correlated ex ante variables characterizing the activity during the policy process. An $F$-test of joint significance $(F=5.65)$ of the three ex ante measures shows a significant effect of the combined effect. An $F$-test of joint significance $(F=10.56)$ of all ex ante and ex post sub-indices indicates a significant influence of the full set of variables. When applying the wild cluster bootstrap-t method we find mostly statistically significant effect. Only the combined measure of ex ante audit and proposal rights does not achieve standard levels of statistical significance. 
Table 2

Hypothesis 1 - disaggregating the auditor index (municipal data 1999).

\begin{tabular}{|c|c|c|c|c|c|c|c|c|}
\hline & $\begin{array}{l}(1) \\
\text { WIS }\end{array}$ & $\begin{array}{l}(2) \\
\text { WIS }\end{array}$ & $\begin{array}{l}(3) \\
\text { WIS }\end{array}$ & $\begin{array}{l}(4) \\
\text { WIS }\end{array}$ & $(5)$ & $\begin{array}{l}\text { (6) } \\
\text { WIS }\end{array}$ & (7) & (8) \\
\hline & & WLS & & & WLS & WLS & WLS & WLS \\
\hline Ex post (scale: $0-1$ ) & $\begin{array}{l}-1.548^{* * *} \\
(0.264)\end{array}$ & $\begin{array}{l}-1.404^{* * *} \\
(0.238)\end{array}$ & & & $\begin{array}{l}-1.003^{* * *} \\
(0.279)\end{array}$ & $\begin{array}{l}-0.781^{* *} \\
(0.358)\end{array}$ & $\begin{array}{l}-1.080^{* * *} \\
(0.270)\end{array}$ & $\begin{array}{l}-0.940^{* * *} \\
(0.317)\end{array}$ \\
\hline Ex ante (scale: $0-2$ ) & & & $\begin{array}{l}-0.807^{* * *} \\
(0.200)\end{array}$ & $\begin{array}{l}-0.757^{\text {*** }} \\
(0.164)\end{array}$ & $\begin{array}{l}-0.440^{*} \\
(0.216)\end{array}$ & $\begin{array}{l}-0.479^{* *} \\
(0.221)\end{array}$ & & \\
\hline Ex ante and proposal (scale: $0-3$ ) & & & & & & & $\begin{array}{l}-0.282^{*} \\
(0.161)\end{array}$ & $\begin{array}{l}-0.273^{*} \\
(0.145)\end{array}$ \\
\hline Local direct democracy & $\begin{array}{l}1.369^{* * *} \\
(0.251)\end{array}$ & $\begin{array}{l}1.041^{* * *} \\
(0.296)\end{array}$ & $\begin{array}{l}1.219^{* * *} \\
(0.231)\end{array}$ & $\begin{array}{l}0.870^{* * *} \\
(0.261)\end{array}$ & $\begin{array}{l}1.424^{* * *} \\
(0.248)\end{array}$ & $\begin{array}{l}1.045^{* * *} \\
(0.291)\end{array}$ & $\begin{array}{l}1.427^{* * *} \\
(0.253)\end{array}$ & $\begin{array}{l}1.069^{* * *} \\
(0.294)\end{array}$ \\
\hline Cantonal direct democracy 1 & $\begin{array}{l}0.139 \\
(0.142)\end{array}$ & $\begin{array}{l}0.066 \\
(0.137)\end{array}$ & $\begin{array}{l}-0.088 \\
(0.116)\end{array}$ & $\begin{array}{l}-0.203^{*} \\
(0.109)\end{array}$ & $\begin{array}{l}0.065 \\
(0.144)\end{array}$ & $\begin{array}{l}-0.054 \\
(0.128)\end{array}$ & $\begin{array}{l}0.093 \\
(0.138)\end{array}$ & $\begin{array}{l}0.005 \\
(0.118)\end{array}$ \\
\hline Federalism & $\begin{array}{l}-1.205^{* * *} \\
(0.172)\end{array}$ & $\begin{array}{l}-1.249^{* * *} \\
(0.208)\end{array}$ & $\begin{array}{l}-1.010^{* * *} \\
(0.182)\end{array}$ & $\begin{array}{l}-1.045^{* * *} \\
(0.215)\end{array}$ & $\begin{array}{l}-1.141^{* * *} \\
(0.160)\end{array}$ & $\begin{array}{l}-1.164^{* * *} \\
(0.197)\end{array}$ & $\begin{array}{l}-1.194^{* * *} \\
(0.152)\end{array}$ & $\begin{array}{l}-1.220^{* * *} \\
(0.192)\end{array}$ \\
\hline Income & $\begin{array}{l}-0.110^{* * *} \\
(0.011)\end{array}$ & $\begin{array}{l}-0.074^{* * *} \\
(0.022)\end{array}$ & $\begin{array}{l}-0.102^{* * *} \\
(0.013)\end{array}$ & $\begin{array}{l}-0.069^{\text {*** }} \\
(0.021)\end{array}$ & $\begin{array}{l}-0.102^{* * *} \\
(0.013)\end{array}$ & $\begin{array}{l}-0.067^{* * *} \\
(0.021)\end{array}$ & $\begin{array}{l}-0.099^{* * *} \\
(0.015)\end{array}$ & $\begin{array}{l}-0.066^{* * *} \\
(0.023)\end{array}$ \\
\hline Population & $\begin{array}{l}3.74 \mathrm{e}-06 \\
(3.92 \mathrm{e}-06)\end{array}$ & $\begin{array}{l}3.52 \mathrm{e}-06 \\
(3.26 \mathrm{e}-06)\end{array}$ & $\begin{array}{l}4.39 e-06 \\
(4.08 e-06)\end{array}$ & $\begin{array}{l}3.28 e-06 \\
(3.43 e-06)\end{array}$ & $\begin{array}{l}3.84 \mathrm{e}-06 \\
(3.88 \mathrm{e}-06)\end{array}$ & $\begin{array}{l}3.33 e-06 \\
(3.42 e-06)\end{array}$ & $\begin{array}{l}3.77 e-06 \\
(3.88 e-06)\end{array}$ & $\begin{array}{l}3.13 e-06 \\
(3.47 e-06)\end{array}$ \\
\hline Language & & $\begin{array}{l}-0.083 \\
(0.271)\end{array}$ & & $\begin{array}{l}-0.275 \\
(0.335)\end{array}$ & & $\begin{array}{l}-0.129 \\
(0.272)\end{array}$ & & $\begin{array}{l}-0.109 \\
(0.265)\end{array}$ \\
\hline Young $(<24)$ & & $\begin{array}{l}8.014^{* *} \\
(3.382)\end{array}$ & & $\begin{array}{l}6.143^{*} \\
(3.518)\end{array}$ & & $\begin{array}{l}7.272^{* *} \\
(3.452)\end{array}$ & & $\begin{array}{l}7.254^{* *} \\
(3.370)\end{array}$ \\
\hline Aged $(>65)$ & & $\begin{array}{l}9.487^{* * *} \\
(1.922)\end{array}$ & & $\begin{array}{l}8.023^{* * *} \\
(1.887)\end{array}$ & & $\begin{array}{l}8.525^{* * *} \\
(1.858)\end{array}$ & & $\begin{array}{l}8.705^{* * *} \\
(1.795)\end{array}$ \\
\hline Unemployed & & $\begin{array}{l}-0.090 \\
(0.185)\end{array}$ & & $\begin{array}{l}-0.230 \\
(0.152)\end{array}$ & & $\begin{array}{l}-0.152 \\
(0.146)\end{array}$ & & $\begin{array}{l}-0.103 \\
(0.152)\end{array}$ \\
\hline Tertiary & & -0.020 & & $-0.027^{*}$ & & $-0.024^{*}$ & & $-0.025^{*}$ \\
\hline Education & & $(0.014)$ & & $(0.014)$ & & $(0.013)$ & & $(0.014)$ \\
\hline Foreigner & & $\begin{array}{l}-0.760 \\
(0.797)\end{array}$ & & $\begin{array}{l}-1.497^{*} \\
(0.746)\end{array}$ & & $\begin{array}{l}-0.990 \\
(0.740)\end{array}$ & & $\begin{array}{l}-0.887 \\
(0.742)\end{array}$ \\
\hline Population density & & $\begin{array}{l}-0.002 \\
(0.005)\end{array}$ & & $\begin{array}{l}-0.005 \\
(0.006)\end{array}$ & & $\begin{array}{l}-0.003 \\
(0.005)\end{array}$ & & $\begin{array}{l}-0.003 \\
(0.005)\end{array}$ \\
\hline Mountain & & $\begin{array}{l}0.782 \\
(0.852)\end{array}$ & & $\begin{array}{l}0.733 \\
(0.925)\end{array}$ & & $\begin{array}{l}0.827 \\
(0.889)\end{array}$ & & $\begin{array}{l}0.822 \\
(0.881)\end{array}$ \\
\hline Agriculture & & $\begin{array}{l}0.910^{* *} \\
(0.414)\end{array}$ & & $\begin{array}{l}0.731 \\
(0.436)\end{array}$ & & $\begin{array}{l}0.851^{* *} \\
(0.405)\end{array}$ & & $\begin{array}{l}0.932^{* *} \\
(0.412)\end{array}$ \\
\hline Industry & & $\begin{array}{l}1.601 \\
(1.375)\end{array}$ & & $\begin{array}{l}0.672 \\
(1.179)\end{array}$ & & $\begin{array}{l}0.875 \\
(1.137)\end{array}$ & & $\begin{array}{l}0.979 \\
(1.149)\end{array}$ \\
\hline Public transportation & & $\begin{array}{l}0.012 \\
(0.013)\end{array}$ & & $\begin{array}{l}0.026^{* *} \\
(0.012)\end{array}$ & & $\begin{array}{l}0.019 \\
(0.011)\end{array}$ & & $\begin{array}{l}0.020^{*} \\
(0.011)\end{array}$ \\
\hline Social democrats & & $\begin{array}{l}0.016^{* *} \\
(0.007)\end{array}$ & & $\begin{array}{l}0.011 \\
(0.010)\end{array}$ & & $\begin{array}{l}0.013 \\
(0.008)\end{array}$ & & $\begin{array}{l}0.013^{*} \\
(0.007)\end{array}$ \\
\hline Observations & 732 & 718 & 732 & 718 & 732 & 718 & 732 & 718 \\
\hline$R$-squared & 0.660 & 0.733 & 0.651 & 0.738 & 0.677 & 0.751 & 0.674 & 0.744 \\
\hline
\end{tabular}

Notes: see Table 1.

Unfortunately, when using the dataset at the cantonal level, some of the sub-indices do not feature sufficient variation to estimate reasonable effects. Furthermore, the cantonal data would also require the indices to be weighted with the prevalence of town meetings (see previous discussion).

\subsection{Hypothesis 1: auditors' influence on taxes and expenditures - cantonal data}

Tables 3 and 4 present the estimates on taxes and expenditures for the dataset at the cantonal level. The data are aggregated at the cantonal level and we face a much smaller data sample that contains only the 26 cantons over several years. Our tables present results from pooled OLS and random effects (RE) regressions with different sets of covariates as well as with and without time effects. We always report a basic regression first, only including a set of the most important variables. Secondly, we include measures of fiscal preferences (Funk and Gathmann, 2005) in order to account for citizens' preferences that potentially drive institutions as well as fiscal outcomes simultaneously. Thirdly, we add time fixed effects to control for time-specific variation and fourthly, we include a full range of different control variables.

\subsubsection{Taxes}

Focusing on the tax data we see from Table 3 that the estimated auditor coefficient is significant in all different regression models. The pooled OLS and the random effects estimates yield significant effects even when standard errors are adjusted for clustering using the wild cluster bootstrap-t method (see Table 9). 
Table 3

Hypothesis 1 - auditors and taxation (cantonal panel dataset 1990-2000).

\begin{tabular}{|c|c|c|c|c|c|c|c|c|}
\hline & $\begin{array}{l}\text { (1) } \\
\text { OLS }\end{array}$ & $\begin{array}{l}\text { (2) } \\
\text { OLS }\end{array}$ & $\begin{array}{l}\text { (3) } \\
\text { OLS }\end{array}$ & $\begin{array}{l}\text { (4) } \\
\text { OLS }\end{array}$ & $\begin{array}{l}\text { (5) } \\
\text { Random } \\
\text { effects }\end{array}$ & $\begin{array}{l}(6) \\
\text { Random } \\
\text { effects }\end{array}$ & $\begin{array}{l}\text { (7) } \\
\text { Random } \\
\text { effects }\end{array}$ & $\begin{array}{l}(8) \\
\text { Random } \\
\text { effects }\end{array}$ \\
\hline Auditor & $\begin{array}{l}-9.241^{* *} \\
(3.667)\end{array}$ & $\begin{array}{l}-8.942^{* * *} \\
(3.044)\end{array}$ & $\begin{array}{l}-9.229^{* *} \\
(3.749)\end{array}$ & $\begin{array}{l}-3.788 \\
(3.524)\end{array}$ & $\begin{array}{l}-11.358^{* * * *} \\
(3.693)\end{array}$ & $\begin{array}{l}-10.248^{* * *} \\
(3.087)\end{array}$ & $\begin{array}{l}-11.920^{* * * *} \\
(3.739)\end{array}$ & $\begin{array}{l}-7.003^{* *} \\
(3.463)\end{array}$ \\
\hline Local direct democracy & $\begin{array}{l}3.547 \\
(10.939)\end{array}$ & $\begin{array}{l}5.403 \\
(10.409)\end{array}$ & $\begin{array}{l}3.620 \\
(11.460)\end{array}$ & $\begin{array}{l}-3.866 \\
(10.821)\end{array}$ & $\begin{array}{l}8.191 \\
(9.229)\end{array}$ & $\begin{array}{l}12.772 \\
(11.807)\end{array}$ & $\begin{array}{l}14.635 \\
(10.479)\end{array}$ & $\begin{array}{l}-2.258 \\
(13.972)\end{array}$ \\
\hline $\begin{array}{r}\text { Cantonal direct } \\
\text { democracy } 1\end{array}$ & $\begin{array}{l}0.399 \\
(4.121)\end{array}$ & $\begin{array}{l}6.599 \\
(3.968)\end{array}$ & $\begin{array}{l}0.351 \\
(4.217)\end{array}$ & $\begin{array}{l}2.285 \\
(4.280)\end{array}$ & $\begin{array}{l}1.666 \\
(3.625)\end{array}$ & $\begin{array}{l}4.002 \\
(4.310)\end{array}$ & $\begin{array}{l}-0.079 \\
(3.552)\end{array}$ & $\begin{array}{l}-0.247 \\
(3.344)\end{array}$ \\
\hline Federalism & $\begin{array}{l}-7.165^{* *} \\
(2.918)\end{array}$ & $\begin{array}{l}-3.309 \\
(4.304)\end{array}$ & $\begin{array}{l}-7.128^{* *} \\
(2.966)\end{array}$ & $\begin{array}{l}-5.267 \\
(3.454)\end{array}$ & $\begin{array}{l}-10.231^{* * *} \\
(3.215)\end{array}$ & $\begin{array}{l}-4.892 \\
(4.885)\end{array}$ & $\begin{array}{l}-9.898^{* * *} \\
(3.595)\end{array}$ & $\begin{array}{l}-6.758^{* *} \\
(3.409)\end{array}$ \\
\hline Income & $\begin{array}{l}-7.86 \mathrm{e}-04^{* *} \\
(3.17 \mathrm{e}-04)\end{array}$ & $\begin{array}{l}-7.49 \mathrm{e}-04^{* *} \\
(2.93 \mathrm{e}-04)\end{array}$ & $\begin{array}{l}-7.87 \mathrm{e}-04^{* *} \\
(3.34 \mathrm{e}-04)\end{array}$ & $\begin{array}{l}-2.97 \mathrm{e}-04 \\
(2.62 \mathrm{e}-04)\end{array}$ & $\begin{array}{l}-3.81 \mathrm{e}-04 \\
(2.67 \mathrm{e}-04)\end{array}$ & $\begin{array}{l}-3.73 e-04 \\
(2.73 e-04)\end{array}$ & $\begin{array}{l}-2.33 e-04 \\
(3.10 e-04)\end{array}$ & $\begin{array}{l}-3.59 \mathrm{e}-04 \\
(2.25 \mathrm{e}-04)\end{array}$ \\
\hline Population & $\begin{array}{l}-2.85 \mathrm{e}-06 \\
(5.79 \mathrm{e}-06)\end{array}$ & $\begin{array}{l}6.73 e-06 \\
(6.81 e-06)\end{array}$ & $\begin{array}{l}-2.80 \mathrm{e}-06 \\
(5.89 \mathrm{e}-06)\end{array}$ & $\begin{array}{l}-1.01 \mathrm{e}-05 \\
(1.09 \mathrm{e}-05)\end{array}$ & $\begin{array}{l}-3.90 e-06 \\
(5.46 e-06)\end{array}$ & $\begin{array}{l}3.63 e-06 \\
(6.81 e-06)\end{array}$ & $\begin{array}{l}-4.75 e-07 \\
(5.99 e-06)\end{array}$ & $\begin{array}{l}-1.54 \mathrm{e}-05 \\
(1.55 \mathrm{e}-05)\end{array}$ \\
\hline $\begin{array}{l}\text { Fiscal } \\
\text { Preference } 1\end{array}$ & & $\begin{array}{l}-28.051 \\
(61.939)\end{array}$ & & & & $\begin{array}{l}-38.807 \\
(72.791)\end{array}$ & & \\
\hline Fiscal & & 24.130 & & & & 15.270 & & \\
\hline Preference 2 & & $(28.426)$ & & & & (32.039) & & \\
\hline Fiscal & & -14.188 & & & & -11.332 & & \\
\hline Preference 3 & & $(20.821)$ & & & & $(22.040)$ & & \\
\hline Population density & & & & $\begin{array}{l}1.525 \\
(0.937)\end{array}$ & & & & $\begin{array}{l}1.137 \\
(0.837)\end{array}$ \\
\hline Aged (>65) & & & & $\begin{array}{l}-42.764 \\
(153.129)\end{array}$ & & & & $\begin{array}{l}44.124 \\
(124.022)\end{array}$ \\
\hline Young $(<18)$ & & & & $\begin{array}{l}352.602^{* *} \\
(168.450)\end{array}$ & & & & $\begin{array}{l}447.292^{* * * *} \\
(170.906)\end{array}$ \\
\hline Unemployed & & & & $\begin{array}{l}2.227^{* * *} \\
(0.539)\end{array}$ & & & & $\begin{array}{l}0.386 \\
(0.413)\end{array}$ \\
\hline Topography & & & & $\begin{array}{l}-0.220 \\
(0.276)\end{array}$ & & & & $\begin{array}{l}-0.088 \\
(0.329)\end{array}$ \\
\hline Industry & & & & $\begin{array}{l}-511.243 \\
(941.079)\end{array}$ & & & & $\begin{array}{l}-96.460 \\
(846.397)\end{array}$ \\
\hline Road length & & & & $\begin{array}{l}0.003^{* * *} \\
(0.001)\end{array}$ & & & & $\begin{array}{l}0.003^{* *} \\
(0.001)\end{array}$ \\
\hline Avg. Rent & & & & $\begin{array}{l}-0.073^{* * * *} \\
(0.017)\end{array}$ & & & & $\begin{array}{l}-0.023^{*} \\
(0.012)\end{array}$ \\
\hline $\begin{array}{l}\text { Class size primary } \\
\text { school }\end{array}$ & & & & $\begin{array}{l}-1.648 \\
(1.356)\end{array}$ & & & & $\begin{array}{l}-2.704^{* *} \\
(1.244)\end{array}$ \\
\hline Conviction rate & & & & $\begin{array}{l}-0.525 \\
(0.325)\end{array}$ & & & & $\begin{array}{l}-0.508^{* *} \\
(0.204)\end{array}$ \\
\hline Time effects & No & No & Yes & No & No & No & Yes & No \\
\hline Observations & 286 & 275 & 286 & 286 & 286 & 275 & 286 & 286 \\
\hline$R$-squared & 0.566 & 0.601 & 0.571 & 0.758 & 0.534 & 0.573 & 0.518 & 0.705 \\
\hline LM Breusch-Pagan & & & & & 726.25 & 599.32 & 746.11 & 293.10 \\
\hline
\end{tabular}

Notes: Robust standard errors in parentheses, adjusted to clustering in 26 cantons. Constant term not reported.

Significance level:

${ }^{*} 0.05<p<0.1$.

$* * 0.01<p<0.05$

*** $p<0.01$.

In column 2 we report the results including the three fiscal preference measures. ${ }^{20}$ We can observe that our results concerning the influence of local auditing institutions are not affected. This is strong evidence that local auditing institutions are not just driven by fiscal preferences and this prominent channel for omitted variable bias is not affecting our results. It can also be observed that other institutional variables such as federalism and direct democracy tend to be affected by the inclusion of these variables. This is in line with the findings by Funk and Gathmann $(2005,2008)$ who show that fiscal preferences have a major direct influence on fiscal outcomes and on the estimated influence of direct democracy. It has to be noted that even if the estimates on the influence of direct democracy and other institutions is affected by the inclusion of fiscal variables, it does not show that these institutions have no direct influence at all. One would expect that, e.g., fiscally conservative citizens with a preference for low taxes and expenditures would install institutions that help them to achieve their preferred policy outcome. Hence, such

\footnotetext{
${ }^{20}$ Factor 1: conservative-liberal attitudes, Factor 2: attitudes favorable to redistribution, Factor 3: attitudes favorable to regulation. For details see Funk and Gathmann (2005).
} 
Table 4

Hypothesis 1 - auditors and expenditures (cantonal panel dataset 1990-2000).

\begin{tabular}{|c|c|c|c|c|c|c|c|c|}
\hline & $\begin{array}{l}(1) \\
\text { OLS }\end{array}$ & $\begin{array}{l}\text { (2) } \\
\text { OLS }\end{array}$ & $\begin{array}{l}\text { (3) } \\
\text { OLS }\end{array}$ & $\begin{array}{l}\text { (4) } \\
\text { OLS }\end{array}$ & $\begin{array}{l}\text { (5) } \\
\text { Random } \\
\text { effects }\end{array}$ & $\begin{array}{l}(6) \\
\text { Random } \\
\text { effects }\end{array}$ & $\begin{array}{l}\text { (7) } \\
\text { Random } \\
\text { effects }\end{array}$ & $\begin{array}{l}(8) \\
\text { Random } \\
\text { effects }\end{array}$ \\
\hline Auditor & $\begin{array}{l}-823.339^{* *} \\
(350.998)\end{array}$ & $\begin{array}{l}-568.803^{* *} \\
(273.336)\end{array}$ & $\begin{array}{l}-556.396^{*} \\
(286.730)\end{array}$ & $\begin{array}{l}-880.962^{* * *} \\
(200.010)\end{array}$ & $\begin{array}{l}-465.364 \\
(370.092)\end{array}$ & $\begin{array}{l}-447.996 \\
(294.610)\end{array}$ & $\begin{array}{l}-392.356^{*} \\
(213.404)\end{array}$ & $\begin{array}{l}-668.243^{* *} \\
(260.228)\end{array}$ \\
\hline Local direct democracy & $\begin{array}{l}-2841.760^{*} \\
(1412.239)\end{array}$ & $\begin{array}{l}-1130.425 \\
(1223.239)\end{array}$ & $\begin{array}{l}-1202.556 \\
(1246.627)\end{array}$ & $\begin{array}{l}-1508.940 \\
(892.022)\end{array}$ & $\begin{array}{l}-2097.426 \\
(1830.873)\end{array}$ & $\begin{array}{l}-629.471 \\
(1496.363)\end{array}$ & $\begin{array}{l}-1695.092 \\
(1688.531)\end{array}$ & $\begin{array}{l}-1077.616 \\
(1336.906)\end{array}$ \\
\hline $\begin{array}{r}\text { Cantonal direct } \\
\text { democracy } 1\end{array}$ & $\begin{array}{l}172.741 \\
(380.183)\end{array}$ & $\begin{array}{l}-284.178 \\
(514.062)\end{array}$ & $\begin{array}{l}-249.831 \\
(530.500)\end{array}$ & $\begin{array}{l}749.356^{* * *} \\
(203.641)\end{array}$ & $\begin{array}{l}-651.088^{* *} \\
(325.778)\end{array}$ & $\begin{array}{l}-715.216^{* *} \\
(341.081)\end{array}$ & $\begin{array}{l}-98.761 \\
(253.585)\end{array}$ & $\begin{array}{l}-366.821 \\
(253.892)\end{array}$ \\
\hline Federalism & $\begin{array}{l}-963.506 \\
(577.089)\end{array}$ & $\begin{array}{l}-562.178 \\
(471.262)\end{array}$ & $\begin{array}{l}-546.265 \\
(495.218)\end{array}$ & $\begin{array}{l}-800.766^{* *} \\
(325.004)\end{array}$ & $\begin{array}{l}46.980 \\
(571.740)\end{array}$ & $\begin{array}{l}-132.589 \\
(460.703)\end{array}$ & $\begin{array}{l}-369.814 \\
(530.592)\end{array}$ & $\begin{array}{l}-483.416 \\
(376.890)\end{array}$ \\
\hline Income & $\begin{array}{l}0.119 * * * \\
(0.036)\end{array}$ & $\begin{array}{l}0.077^{* *} \\
(0.037)\end{array}$ & $\begin{array}{l}0.073^{*} \\
(0.041)\end{array}$ & $\begin{array}{l}0.061^{* * *} \\
(0.017)\end{array}$ & $\begin{array}{l}0.057^{* * *} \\
(0.011)\end{array}$ & $\begin{array}{l}0.058^{* * *} \\
(0.010)\end{array}$ & $\begin{array}{l}0.024 \\
(0.016)\end{array}$ & $\begin{array}{l}0.033^{* *} \\
(0.015)\end{array}$ \\
\hline Population & $\begin{array}{l}-4.06 e-3 \\
(1.03 e-3)\end{array}$ & $\begin{array}{l}-1.41 \mathrm{e}-3 \\
(1.06 \mathrm{e}-3)\end{array}$ & $\begin{array}{l}-1.41 \mathrm{e}-3 \\
(1.09 \mathrm{e}-3)\end{array}$ & $\begin{array}{l}3.95 e-3^{* * *} \\
(1.31 \mathrm{e}-3)\end{array}$ & $\begin{array}{l}1.54 \mathrm{e}-3 \\
(1.29 \mathrm{e}-3)\end{array}$ & $\begin{array}{l}3.81 e-3 \\
(1.67 e-3)\end{array}$ & $\begin{array}{l}-2.11 \mathrm{e}-3^{*} \\
(1.27 \mathrm{e}-3)\end{array}$ & $\begin{array}{l}-1.22 \mathrm{e}-3 \\
(2.39 \mathrm{e}-3)\end{array}$ \\
\hline Topography & $\begin{array}{l}98.222^{* * *} \\
(25.344)\end{array}$ & $\begin{array}{l}17.867 \\
(45.558)\end{array}$ & $\begin{array}{l}16.218 \\
(47.878)\end{array}$ & $\begin{array}{l}33.579 \\
(26.973)\end{array}$ & $\begin{array}{l}52.221 \\
(38.030)\end{array}$ & $\begin{array}{l}5.096 \\
(41.577)\end{array}$ & $\begin{array}{l}-11.575 \\
(35.130)\end{array}$ & $\begin{array}{l}19.936 \\
(47.452)\end{array}$ \\
\hline $\begin{array}{l}\text { Fiscal } \\
\text { Preference } 1\end{array}$ & & $\begin{array}{l}-17.09 \mathrm{e} 3^{* *} \\
(8.11 \mathrm{e} 3)\end{array}$ & $\begin{array}{l}-17.08 \mathrm{e} 3^{* *} \\
(8.23 \mathrm{e} 3)\end{array}$ & $\begin{array}{l}-1.23 \mathrm{e} 3 \\
(5.25 \mathrm{e} 3)\end{array}$ & & $\begin{array}{l}-17.20 \mathrm{e}^{*} \\
(9.48 \mathrm{e} 3)\end{array}$ & $\begin{array}{l}-17.25 \mathrm{e} 3^{* *} \\
(7.60 \mathrm{e} 3)\end{array}$ & $\begin{array}{l}-14.26 \mathrm{e} 3 \\
(1.07 \mathrm{e} 3)\end{array}$ \\
\hline $\begin{array}{l}\text { Fiscal } \\
\text { Preference? }\end{array}$ & & $-1.91 \mathrm{e} 3$ & $-1.80 \mathrm{e} 3$ & $3.16 \mathrm{e}^{*}$ & & $-2.47 \mathrm{e} 3$ & $-0.77 \mathrm{e} 3$ & $-1.17 \mathrm{e} 3$ \\
\hline $\begin{array}{l}\text { Preference } 2 \\
\text { Fiscal }\end{array}$ & & $\begin{array}{l}(3.06 \mathrm{e} 3) \\
9.42 \mathrm{e}^{* *}\end{array}$ & $\begin{array}{l}(3.12 \mathrm{e} 3) \\
9.44 \mathrm{e}^{* *}\end{array}$ & $\begin{array}{l}(1.54 \mathrm{e} 3) \\
2.53 \mathrm{e} 3\end{array}$ & & $\begin{array}{l}(2.95 \mathrm{e} 3) \\
9.40 \mathrm{e} 3^{* *}\end{array}$ & $\begin{array}{l}(2.75 \mathrm{e} 3) \\
10.73 \mathrm{e} 3^{* *}\end{array}$ & $\begin{array}{l}(3.02 \mathrm{e} 3) \\
7.96 \mathrm{e}^{*}\end{array}$ \\
\hline Preference 3 & & $(4.07 \mathrm{e} 3)$ & $(4.23 \mathrm{e} 3)$ & $(2.62 \mathrm{e} 3)$ & & $(3.97 \mathrm{e} 3)$ & $(4.25 \mathrm{e} 3)$ & $(4.75 \mathrm{e} 3)$ \\
\hline Population density & & & & $\begin{array}{l}315.463^{* * *} \\
(55.870)\end{array}$ & & & & $\begin{array}{l}62.700 \\
(130.973)\end{array}$ \\
\hline Aged $(>65)$ & & & & $\begin{array}{l}-4.72 \mathrm{e} 3 \\
(13.87 \mathrm{e} 3)\end{array}$ & & & & $\begin{array}{l}5.96 \mathrm{e} 3 \\
(8.19 \mathrm{e} 3)\end{array}$ \\
\hline Young $(<18)$ & & & & $\begin{array}{l}15.33 \mathrm{e} 3 \\
(12.44 \mathrm{e} 3)\end{array}$ & & & & $\begin{array}{l}19.42 \mathrm{e}^{*} \\
(10.26 \mathrm{e} 3)\end{array}$ \\
\hline Unemployed & & & & $\begin{array}{l}109.442^{*} \\
(56.738)\end{array}$ & & & & $\begin{array}{l}7.186 \\
(39.233)\end{array}$ \\
\hline Industry & & & & $\begin{array}{l}-2.69 \mathrm{e} 5^{* * *} \\
(0.49 \mathrm{e} 5)\end{array}$ & & & & $\begin{array}{l}3.34 \mathrm{e} 3 \\
(1.15 \mathrm{e} 5)\end{array}$ \\
\hline Road length & & & & $\begin{array}{l}-0.370^{* * * *} \\
(0.108)\end{array}$ & & & & $\begin{array}{l}-0.003 \\
(0.187)\end{array}$ \\
\hline Avg. Rent & & & & $\begin{array}{l}2.549^{* *} \\
(0.994)\end{array}$ & & & & $\begin{array}{l}4.485^{* * *} \\
(0.782)\end{array}$ \\
\hline Class size primary school & & & & $\begin{array}{l}-369.205^{*} \\
(199.446)\end{array}$ & & & & $\begin{array}{l}-246.475^{* *} \\
(101.989)\end{array}$ \\
\hline Conviction rate & & & & $\begin{array}{l}211.487^{* * *} \\
(39.855)\end{array}$ & & & & $\begin{array}{l}35.556 * * \\
(13.978)\end{array}$ \\
\hline Time effects & No & No & Yes & No & No & No & Yes & No \\
\hline Observations & 286 & 275 & 275 & 275 & 286 & 275 & 275 & 275 \\
\hline$R$-squared & 0.608 & 0.739 & 0.753 & 0.905 & 0.475 & 0.682 & 0.731 & 0.802 \\
\hline LM Breusch-Pagan & & & & & 1071 & 944.3 & 1068 & 312.7 \\
\hline
\end{tabular}

Notes: see Table 3.

institutions might nevertheless have a direct impact on fiscal outcomes. ${ }^{21}$ Adding time effects in columns 3 and 7 does not alter the results. The coefficient is fairly stable in most specifications, but the extensive set of control variables in columns 4 and 8 . This however, is not surprising, since we include a great number of explanatory variables, while we only feature a limited number of relevant cross-sectional observations.

The overall effect of the auditor variable is again not only statistically, but also economically significant. When comparing a canton with municipalities featuring the weakest form of auditors with one featuring the most powerful auditing institution, the potential effect on taxes comes to roughly $25 \%$ tax relief (16-17\% in local dataset). The difference to the estimates in the local dataset could be due to lower precision of the cantonal level regressions, since they have to rely on fewer crosssection observations. Moreover, the cantonal tax measure is constructed slightly differently than the local tax measure. At the local level the average tax burden is calculated as the mean of the individual tax rates for the income classes between 40,000 and 200,000 CHF. This procedure takes into account that the composition of the extremes of the income distribution below and above the chosen bandwidth could be different across municipalities. Hence, the analysis primarily focuses on the most relevant intermediate income segments. As discussed before, the results are almost identical when analyzing the full 
income spectrum. At the cantonal level the approach of the federal tax administration to construct the tax burden index is similar in that they also focus on the well populated income segments. However, they weight the tax data according to the cantonal income distribution, information which is not available at the local level.

The patterns of the estimated coefficients of the control variables are comparable to the ones in the previous analyses using local level data. At the cantonal level however, the local direct democracy measure does not typically attain statistical significance.

\subsubsection{Expenditures}

When analyzing expenditure data (Table 4) we find additional evidence for our theoretical predictions that powerful auditors significantly reduce total public expenditures. We find statistically significant estimates for almost all different estimation procedures and specifications. The interpretation of the coefficient is straightforward: a one point increase in the auditor variable reduces expenditures between roughly 450 and 850 CHF per capita, which results in a potential effect of around 11$21 \%$ lower expenditures. ${ }^{22}$

In some RE specifications the estimated auditor coefficient does not reach conventional levels of statistical significance. Again, it is not surprising that the estimates using data aggregated at the cantonal level are more sensitive to the simultaneous inclusion of many different variables. The number of cantons is constraining and the yearly observations cannot be considered completely independent. In this light, the results are even more striking that we always find a large negative - and in nearly all cases statistically significant - impact of auditors on government expenditures. Moreover, we can observe that the inclusion of the fiscal preference measures do once more not affect our results. This time however, fiscal preferences have a significant influence on our dependent variable and we include these measures in all subsequent specifications.

In summary, as suggested by Hypothesis 1 , more powerful auditors significantly reduce taxes and expenditures. The effects are not only statistically significant, but they are also large and economically highly relevant. The effect of direct democracy is not robust and remains inconclusive, though overall, they are not inconsistent with more recent results. The estimates concerning decentralization are negative and largely agree with the literature and other studies for Switzerland. As we expected, income affects expenditures and taxes, whereas the population measure does not impact on expenditures. ${ }^{23}$

\subsection{Hypothesis 2: auditors' influence conditional on municipal size - municipal data}

According to Hypothesis 2, larger municipalities face a more pronounced control and collective action problem than smaller municipalities. In smaller towns, citizens might be better able to overcome the free-rider problem. Thus, the broader interests are better organized and the asymmetry between general common pool and special interests is smaller. Furthermore, in smaller towns it should be easier to monitor the government, because their problems and policies are less complex, and social ties might induce public officials not to deviate too much from citizens' preferences since they could suffer social censure. Therefore, the control and the collective action problem should be more pronounced in larger municipalities. Hence, the impact of auditors with an extended mandate should (cet. par.) be higher in such municipalities. We test this hypothesis by estimating an interaction term of our auditor variable with the population size.

The results in Table 5 report empirical support for this hypothesis. In most specifications the interaction term of the auditor with the population variable has a statistically significant negative influence on tax rates. The estimates are robust to variations in model specifications and to the inclusion of additional controls. The estimated effect of the auditor variable by itself remains almost unaffected. Also the estimates of the other variables are robust to the inclusion of the interaction term. The result suggests that auditors with an extensive auditing mandate are especially beneficial in large municipalities with a more pronounced control and collective action problem.

The size of the effect is straightforward: in a median sized municipality with 4170 citizens the effect of a one point stronger auditor amounts to 0.43 percentage point lower tax rate, compared to a municipality in the 90-percentile with a population size of 13,777 citizens the effect amounts to a 0.67 percentage point lower tax rate. Thus, the potential effect for going from the weakest to the strongest form of auditor is roughly $12 \%$ lower taxes for a median size municipality and $18.5 \%$ lower taxes for a municipality in the 90 -percentile.

\subsection{Robustness}

In order to provide further evidence for the robustness of our results, we present estimates including a widely used alternative measure of cantonal direct democracy and different sampling weights for the regressions using municipal tax data. Furthermore, we report the results for alternative empirical strategies concerning our cantonal panel data estimates. We present results for regressions on cantonal means (between effects estimators) and for fixed effects vector decomposition

\footnotetext{
${ }^{22}$ We also estimated the effects using log specifications. The estimates are very similar and available upon request.

${ }^{23}$ Estimating log specifications did not change our main findings. However, the squared term of the population measure sometimes had a small positive significant impact.
} 
Table 5

Hypothesis 2 - auditors' influence in large vs. small jurisdictions (municipal data 1999).

\begin{tabular}{|c|c|c|c|c|c|}
\hline & $\begin{array}{l}(1) \\
\text { OLS }\end{array}$ & $\begin{array}{l}(2) \\
\text { OLS }\end{array}$ & $\begin{array}{l}(3) \\
\text { WLS }\end{array}$ & $\begin{array}{l}(4) \\
\text { WLS }\end{array}$ & $\begin{array}{l}(5) \\
\text { WLS }\end{array}$ \\
\hline Auditor & $\begin{array}{l}-0.604^{* * *} \\
(0.078)\end{array}$ & $\begin{array}{l}-0.498^{* * *} \\
(0.094)\end{array}$ & $\begin{array}{l}-0.483^{* * *} \\
(0.114)\end{array}$ & $\begin{array}{l}-0.377^{* * *} \\
(0.133)\end{array}$ & $\begin{array}{l}-0.327^{* * *} \\
(0.098)\end{array}$ \\
\hline Auditor $*$ population & & $\begin{array}{l}-2.10 \mathrm{e}-05 \\
(1.34 \mathrm{e}-05)\end{array}$ & & $\begin{array}{l}-2.42 \mathrm{e}-05^{*} \\
(1.21 \mathrm{e}-05)\end{array}$ & $\begin{array}{l}-2.52 \mathrm{e}-05^{*} \\
(1.18 \mathrm{e}-05)\end{array}$ \\
\hline Local direct democracy & $\begin{array}{l}1.261^{* * * *} \\
(0.248)\end{array}$ & $\begin{array}{l}1.285^{* * * *} \\
(0.244)\end{array}$ & $\begin{array}{l}1.349^{* * *} \\
(0.227)\end{array}$ & $\begin{array}{l}1.366^{* * * *} \\
(0.226)\end{array}$ & $\begin{array}{l}1.039^{* * *} \\
(0.271)\end{array}$ \\
\hline Cantonal direct democracy 1 & $\begin{array}{l}0.058 \\
(0.106)\end{array}$ & $\begin{array}{l}0.049 \\
(0.104)\end{array}$ & $\begin{array}{l}0.016 \\
(0.133)\end{array}$ & $\begin{array}{l}0.023 \\
(0.127)\end{array}$ & $\begin{array}{l}-0.064 \\
(0.113)\end{array}$ \\
\hline Federalism & $\begin{array}{l}-1.213^{* * *} \\
(0.241)\end{array}$ & $\begin{array}{l}-1.215^{\text {*** }} \\
(0.236)\end{array}$ & $\begin{array}{l}-1.150^{* * *} \\
(0.160)\end{array}$ & $\begin{array}{l}-1.168^{* * *} \\
(0.158)\end{array}$ & $\begin{array}{l}-1.176^{* * *} \\
(0.199)\end{array}$ \\
\hline Income & $\begin{array}{l}-0.080^{* * *} \\
(0.012)\end{array}$ & $\begin{array}{l}-0.077^{* * *} \\
(0.011)\end{array}$ & $\begin{array}{l}-0.096^{* * *} \\
(0.015)\end{array}$ & $\begin{array}{l}-0.091^{* * *} \\
(0.013)\end{array}$ & $\begin{array}{l}-0.061^{* * *} \\
(0.021)\end{array}$ \\
\hline Population & $\begin{array}{l}1.59 \mathrm{e}-06 \\
(3.63 e-06)\end{array}$ & $\begin{array}{l}2.47 \mathrm{e}-06 \\
(3.95 \mathrm{e}-06)\end{array}$ & $\begin{array}{l}4.01 e-06 \\
(3.97 e-06)\end{array}$ & $\begin{array}{l}4.97 e-06 \\
(4.19 e-06)\end{array}$ & $\begin{array}{l}3.19 e-06 \\
(3.61 e-06)\end{array}$ \\
\hline Language & & & & & $\begin{array}{l}-0.202 \\
(0.282)\end{array}$ \\
\hline Young $(<24)$ & & & & & $\begin{array}{l}6.269^{*} \\
(3.225)\end{array}$ \\
\hline Aged $(>65)$ & & & & & $\begin{array}{l}8.574^{* * *} \\
(1.789)\end{array}$ \\
\hline Unemployed & & & & & $\begin{array}{l}-0.121 \\
(0.145)\end{array}$ \\
\hline Tertiary education & & & & & $\begin{array}{l}-0.029^{* *} \\
(0.014)\end{array}$ \\
\hline Foreigner & & & & & $\begin{array}{l}-0.993 \\
(0.711)\end{array}$ \\
\hline Population density & & & & & $\begin{array}{l}-0.006 \\
(0.006)\end{array}$ \\
\hline Mountain & & & & & $\begin{array}{l}0.901 \\
(0.890)\end{array}$ \\
\hline Agriculture & & & & & $\begin{array}{l}0.965^{* *} \\
(0.442)\end{array}$ \\
\hline Industry & & & & & $\begin{array}{l}1.580 \\
(1.173)\end{array}$ \\
\hline Public transportation & & & & & $\begin{array}{l}0.030^{* *} \\
(0.013)\end{array}$ \\
\hline Social democrats & & & & & $\begin{array}{l}0.012 \\
(0.009)\end{array}$ \\
\hline Observations & 732 & 732 & 732 & 732 & 718 \\
\hline$R$-squared & 0.711 & 0.717 & 0.664 & 0.670 & 0.744 \\
\hline
\end{tabular}

See Table 1.

models. Furthermore, we present results using the wild cluster bootstrap-t procedure, which is an alternative method to adjust standard errors for within-group dependence. A brief discussion of further robustness tests including alternative fiscal variables is also provided.

\subsubsection{Alternative direct democracy variable}

As can be seen from Table 6 the choice of the direct democracy variable does not substantially affect the coefficients of the direct democracy variables or our variable of interest concerning the auditor mandate. The direct democracy variables and the auditor variable are similar in size and significance when employing the dummy for whether a canton features a mandatory financial referendum (e.g., Feld and Matsusaka, 2003) compared to the results including the encompassing index of direct democracy (Stutzer, 1999).

\subsubsection{Alternative weights in the WLS regressions}

As has been discussed above, the sample of 730 municipalities might not only depend on the number of municipalities in a canton, but also on the population size. When adjusting the weights to also take the population size into account we find largely identical results (Table 7). When analyzing the interaction effect of population size and auditing (Hypothesis 2) the estimated coefficient is similar in size but does not attain statistical significance by a thin margin ( $p$-values of 0.11 ). From this perspective it is safe to argue that the results are robust to the alternative sampling weights. 
Table 6

Robustness - alternative cantonal direct democracy measure.

\begin{tabular}{|c|c|c|c|c|c|c|c|c|}
\hline & \multicolumn{2}{|c|}{$\begin{array}{l}\text { Municipal dataset } \\
\text { WLS }\end{array}$} & \multicolumn{4}{|c|}{$\begin{array}{l}\text { Cantonal panel dataset (1990-2000) } \\
\text { Random effects }\end{array}$} & \multicolumn{2}{|c|}{$\begin{array}{l}\text { Municipal dataset } \\
\text { WLS }\end{array}$} \\
\hline & $\begin{array}{l}\text { Tax } \\
(1)\end{array}$ & $\begin{array}{l}\text { Tax } \\
(2)\end{array}$ & $\begin{array}{l}\text { Tax } \\
(3)\end{array}$ & $\begin{array}{l}\text { Tax } \\
(4)\end{array}$ & $\begin{array}{l}\text { Expenditure } \\
(5)\end{array}$ & $\begin{array}{l}\text { Expenditure } \\
(6)\end{array}$ & $\begin{array}{l}\text { Tax } \\
(7)\end{array}$ & $\begin{array}{l}\text { Tax } \\
(8)\end{array}$ \\
\hline Auditor & $\begin{array}{l}-0.421^{* * *} \\
(0.099)\end{array}$ & $\begin{array}{l}-0.416^{* * *} \\
(0.079)\end{array}$ & $\begin{array}{l}-10.627^{* * *} \\
(3.473)\end{array}$ & $\begin{array}{l}-6.379^{* *} \\
(2.756)\end{array}$ & $\begin{array}{l}-594.010^{*} \\
(315.924)\end{array}$ & $\begin{array}{l}-640.130^{* *} \\
(276.540)\end{array}$ & $\begin{array}{l}-0.324^{* *} \\
(0.121)\end{array}$ & $\begin{array}{l}-0.308^{* * *} \\
(0.088)\end{array}$ \\
\hline Auditor $*$ population & & & & & & & $\begin{array}{l}-2.23 \mathrm{e}-05 \\
(1.32 \mathrm{e}-05)\end{array}$ & $\begin{array}{l}-2.54 \mathrm{e}-05^{*} \\
(1.23 \mathrm{e}-05)\end{array}$ \\
\hline Local direct democracy & $\begin{array}{l}1.157^{* * *} \\
(0.251)\end{array}$ & $\begin{array}{l}0.948^{* * *} \\
(0.285)\end{array}$ & $\begin{array}{l}8.721 \\
(7.978)\end{array}$ & $\begin{array}{l}3.918 \\
(14.889)\end{array}$ & $\begin{array}{l}-3.07 \mathrm{e} 3^{* * *} \\
(1.56 \mathrm{e} 3)\end{array}$ & $\begin{array}{c}-1,38 \mathrm{e} 3 \\
(1.26 \mathrm{e} 3)\end{array}$ & $\begin{array}{l}1.184^{* * *} \\
(0.254)\end{array}$ & $\begin{array}{l}0.997^{* * *} \\
(0.287)\end{array}$ \\
\hline Cantonal direct democracy 2 & $\begin{array}{l}0.378 \\
(0.278)\end{array}$ & $\begin{array}{l}0.156 \\
(0.214)\end{array}$ & $\begin{array}{l}4.125 \\
(3.064)\end{array}$ & $\begin{array}{l}1.390 \\
(2.800)\end{array}$ & $\begin{array}{l}63.799 \\
(189.570)\end{array}$ & $\begin{array}{l}256.037 \\
(158.711)\end{array}$ & $\begin{array}{l}0.365 \\
(0.281)\end{array}$ & $\begin{array}{l}0.149 \\
(0.212)\end{array}$ \\
\hline Federalism & $\begin{array}{l}-1.147^{* * * *} \\
(0.200)\end{array}$ & $\begin{array}{l}-1.171^{* * * *} \\
(0.207)\end{array}$ & $\begin{array}{l}-9.000^{* * * *} \\
(3.076)\end{array}$ & $\begin{array}{l}-2.830 \\
(4.774)\end{array}$ & $\begin{array}{l}-403.695 \\
(543.299)\end{array}$ & $\begin{array}{l}-546.802 \\
(416.651)\end{array}$ & $\begin{array}{l}-1.159^{* * * *} \\
(0.201)\end{array}$ & $\begin{array}{l}-1.178^{* * *} \\
(0.205)\end{array}$ \\
\hline Income & $\begin{array}{l}-0.092^{* * *} \\
(0.015)\end{array}$ & $\begin{array}{l}-0.064^{* *} \\
(0.024)\end{array}$ & $\begin{array}{r}-3.81 \mathrm{e}-04 \\
(2.71 \mathrm{e}-04)\end{array}$ & $\begin{array}{l}-4.18 \mathrm{e}-04^{*} \\
(2.18 \mathrm{e}-04)\end{array}$ & $\begin{array}{l}0.061^{* * *} \\
(0.009)\end{array}$ & $\begin{array}{l}0.033^{* *} \\
(0.015)\end{array}$ & $\begin{array}{l}-0.088^{* * *} \\
(0.014)\end{array}$ & $\begin{array}{l}-0.060^{* *} \\
(0.022)\end{array}$ \\
\hline Population & $\begin{array}{l}3.38 e-06 \\
(3.67 e-06)\end{array}$ & $\begin{array}{l}2.96 \mathrm{e}-06 \\
(3.47 \mathrm{e}-06)\end{array}$ & $\begin{array}{r}-3.64 \mathrm{e}-06 \\
(5.35 \mathrm{e}-06)\end{array}$ & $\begin{array}{r}-1.35 \mathrm{e}-05 \\
(1.80 \mathrm{e}-05)\end{array}$ & $\begin{array}{l}1.73 e-03 \\
(1.22 \mathrm{e}-03)\end{array}$ & $\begin{array}{l}-1.98 \mathrm{e}-03 \\
(2.71 \mathrm{e}-03)\end{array}$ & $\begin{array}{l}4.33 e-06 \\
(3.84 e-06)\end{array}$ & $\begin{array}{l}3.22 \mathrm{e}-06 \\
(3.59 \mathrm{e}-06)\end{array}$ \\
\hline Additional controls & No & Yes & No & Yes & No & Yes & No & Yes \\
\hline Observations & 732 & 718 & 286 & 275 & 286 & 275 & 732 & 718 \\
\hline$R$-squared & 0.676 & 0.738 & 0.522 & 0.708 & 0.530 & 0.800 & 0.681 & 0.745 \\
\hline LM Breusch-Pagan & & & 696.1 & 316.4 & 1051 & 402.6 & & \\
\hline
\end{tabular}

Notes: Robust standard errors in parentheses, adjusted to clustering in 26 cantons. Cantonal direct democracy measure: dummy variable for whether cantons have a mandatory financial referendum. Additional controls municipal data: Language, share of young and aged, unemployment, tertiary education, share of foreigners, population density, mountainous, agricultural, industrial fraction, public transportation, social democrats. Additional controls cantonal data: Fiscal preferences, share of young and aged, unemployment, share of foreigners, population density, topography, industrial fraction, road length, avg. rent, class size primary school, conviction rates. Constant term not reported.

Significance level:

$* 0.05<p<0.1$.

*** $0.01<p<0.05$.

*** $p<0.01$

\subsubsection{Alternative panel data estimation}

Table 8 presents results applying alternative panel data models. Columns 1-4 present regressions on cantonal means (between effects estimators). The results are once again similar to the previous ones employing OLS and random effects

Table 7

Robustness - alternative sampling weights (municipal data).

\begin{tabular}{|c|c|c|c|c|}
\hline & $\begin{array}{l}(1) \\
\text { WLS }\end{array}$ & $\begin{array}{l}(2) \\
\text { WLS }\end{array}$ & $\begin{array}{l}(3) \\
\text { WLS }\end{array}$ & $\begin{array}{l}(4) \\
\text { WLS }\end{array}$ \\
\hline Auditor & $\begin{array}{l}-0.551^{\text {**** }} \\
(0.103)\end{array}$ & $\begin{array}{l}-0.447^{* * *} \\
(0.079)\end{array}$ & $\begin{array}{l}-0.465^{* * *} \\
(0.135)\end{array}$ & $\begin{array}{l}-0.390^{* * *} \\
(0.094)\end{array}$ \\
\hline Auditor $*$ population & & & $\begin{array}{l}-2.19 \mathrm{e}-05 \\
(1.34 \mathrm{e}-05)\end{array}$ & $\begin{array}{c}-1.51 e-05 \\
(9.34 e-06)\end{array}$ \\
\hline Local direct democracy & $\begin{array}{l}1.507^{* * * *} \\
(0.256)\end{array}$ & $\begin{array}{l}0.981^{* *} \\
(0.382)\end{array}$ & $\begin{array}{l}1.533^{* * * *} \\
(0.258)\end{array}$ & $\begin{array}{c}1.014^{* *} \\
(0.385)\end{array}$ \\
\hline Cantonal direct democracy 1 & $\begin{array}{l}0.088 \\
(0.145)\end{array}$ & $\begin{array}{l}-0.002 \\
(0.112)\end{array}$ & $\begin{array}{l}0.076 \\
(0.143)\end{array}$ & $\begin{array}{l}-0.006 \\
(0.108)\end{array}$ \\
\hline Federalism & $\begin{array}{l}-1.348^{* * *} \\
(0.190)\end{array}$ & $\begin{array}{l}-1.456^{* * *} \\
(0.196)\end{array}$ & $\begin{array}{l}-1.340^{* * *} \\
(0.185)\end{array}$ & $\begin{array}{l}-1.450^{* * *} \\
(0.195)\end{array}$ \\
\hline Income & $\begin{array}{l}-0.076^{* * * *} \\
(0.013)\end{array}$ & $\begin{array}{l}-0.026 \\
(0.015)\end{array}$ & $\begin{array}{l}-0.075^{* * *} \\
(0.012)\end{array}$ & $\begin{array}{l}-0.025 \\
(0.015)\end{array}$ \\
\hline Population & $\begin{array}{l}-2.51 \mathrm{e}-07 \\
(1.13 \mathrm{e}-05)\end{array}$ & $\begin{array}{l}8.30 e-06 \\
(9.05 e-06)\end{array}$ & $\begin{array}{l}7.67 \mathrm{e}-06 \\
(1.09 \mathrm{e}-05)\end{array}$ & $\begin{array}{l}1.31 \mathrm{e}-05 \\
(8.65 \mathrm{e}-06)\end{array}$ \\
\hline Additional controls & No & Yes & No & Yes \\
\hline Observations & 732 & 718 & 732 & 718 \\
\hline$R$-squared & 0.789 & 0.861 & 0.792 & 0.863 \\
\hline
\end{tabular}

Notes: Sampling weights: inverse probability of inclusion in sample (relative number of municipalities per canton and relative municipal population size).

Further details see Table 1. 
Robustness - alternative panel data models (cantonal panel data 1990-2000).

\begin{tabular}{|c|c|c|c|c|c|c|c|c|}
\hline & \multicolumn{4}{|c|}{ Between effects } & \multicolumn{4}{|c|}{ Fixed effects vector decomposition } \\
\hline & $\begin{array}{l}\text { Tax } \\
(1)\end{array}$ & $\begin{array}{l}\operatorname{Tax} \\
(2)\end{array}$ & $\begin{array}{l}\text { Expenditure } \\
(3)\end{array}$ & $\begin{array}{l}\text { Expenditure } \\
(4)\end{array}$ & $\begin{array}{l}\text { Tax } \\
(5)\end{array}$ & $\begin{array}{l}\text { Tax } \\
(6)\end{array}$ & $\begin{array}{l}\text { Expenditure } \\
(7)\end{array}$ & $\begin{array}{l}\text { Expenditure } \\
(8)\end{array}$ \\
\hline Auditor & $\begin{array}{l}-8.900^{* *} \\
(3.392)\end{array}$ & $\begin{array}{l}0.966 \\
(4.182)\end{array}$ & $\begin{array}{l}-882.808^{*} \\
(483.598)\end{array}$ & $\begin{array}{l}-908.523 \\
(588.715)\end{array}$ & $\begin{array}{l}-10.084^{* * *} \\
(0.532)\end{array}$ & $\begin{array}{l}-4.000^{* * *} \\
(0.660)\end{array}$ & $\begin{array}{l}-1.68 \mathrm{e} 3^{* * *} \\
(44.192)\end{array}$ & $\begin{array}{l}-395.962^{* * *} \\
(49.131)\end{array}$ \\
\hline Local direct democracy & $\begin{array}{l}2.163 \\
(13.133)\end{array}$ & $\begin{array}{l}-33.384 \\
(22.995)\end{array}$ & $\begin{array}{l}-2688.603 \\
(1817.071)\end{array}$ & $\begin{array}{l}-1775.182 \\
(3237.468)\end{array}$ & $\begin{array}{l}8.780^{* * *} \\
(2.041)\end{array}$ & $\begin{array}{l}-136.583^{* * *} \\
(7.922)\end{array}$ & $\begin{array}{l}-704.682^{* * *} \\
(157.784)\end{array}$ & $\begin{array}{l}-3.16 \mathrm{e}^{* * *} \\
(229.414)\end{array}$ \\
\hline $\begin{array}{l}\text { Cantonal direct democracy } \\
\quad 1\end{array}$ & $\begin{array}{l}0.477 \\
(3.719)\end{array}$ & $\begin{array}{l}7.391 \\
(5.631)\end{array}$ & $\begin{array}{l}203.525 \\
(529.754)\end{array}$ & $\begin{array}{l}1082.012 \\
(792.763)\end{array}$ & $\begin{array}{l}-2.128^{* * *} \\
(0.584)\end{array}$ & $\begin{array}{l}107.248^{* * *} \\
(5.422)\end{array}$ & $\begin{array}{l}1.89 \mathrm{e} 3^{* * *} \\
(56.193)\end{array}$ & $\begin{array}{l}1.42 \mathrm{e} 3^{* * *} \\
(74.452)\end{array}$ \\
\hline Federalism & $\begin{array}{l}-6.786 \\
(4.555)\end{array}$ & $\begin{array}{l}1.122 \\
(6.750)\end{array}$ & $\begin{array}{l}-1059.678 \\
(703.128)\end{array}$ & $\begin{array}{l}-1059.840 \\
(950.298)\end{array}$ & $\begin{array}{l}-9.332^{* * *} \\
(0.719)\end{array}$ & $\begin{array}{l}26.304^{* * *} \\
(1.849)\end{array}$ & $\begin{array}{l}-1.02 \mathrm{e} 3^{* * *} \\
(59.231)\end{array}$ & $\begin{array}{l}311.641^{* * *} \\
(82.666)\end{array}$ \\
\hline Income & $\begin{array}{l}-0.001^{* *} \\
(0.000)\end{array}$ & $\begin{array}{l}0.000 \\
(0.001)\end{array}$ & $\begin{array}{l}0.130^{* *} \\
(0.051)\end{array}$ & $\begin{array}{l}0.074 \\
(0.091)\end{array}$ & $\begin{array}{l}-2.86 \mathrm{e}-04^{* * *} \\
(4.08 \mathrm{e}-05)\end{array}$ & $\begin{array}{l}-3.01 \mathrm{e}-04^{* * *} \\
(5.51 \mathrm{e}-05)\end{array}$ & $\begin{array}{l}0.049 * * * \\
(0.004)\end{array}$ & $\begin{array}{l}0.014^{* *} \\
(0.005)\end{array}$ \\
\hline Population & $\begin{array}{l}-2.64 \mathrm{e}-06 \\
(1.00 \mathrm{e}-05)\end{array}$ & $\begin{array}{l}-5.60 \mathrm{e}-06 \\
(2.34 \mathrm{e}-05)\end{array}$ & $\begin{array}{l}-4.24 \mathrm{e}-04 \\
(1.38 \mathrm{e}-03)\end{array}$ & $\begin{array}{l}3.86 \mathrm{e}-03 \\
(3.29 \mathrm{e}-03)\end{array}$ & $\begin{array}{l}-3.13 \mathrm{e}-05^{* * *} \\
(3.96 \mathrm{e}-07)\end{array}$ & $\begin{array}{l}2.80 \mathrm{e}-04^{* * *} \\
(9.40 \mathrm{e}-06)\end{array}$ & $\begin{array}{l}0.022^{* * *} \\
(0.000)\end{array}$ & $\begin{array}{l}-0.002^{* * *} \\
(0.000)\end{array}$ \\
\hline$e_{i}$ & & & & & $\begin{array}{l}1.000^{* * *} \\
(0.036)\end{array}$ & $\begin{array}{l}1.000^{* * *} \\
(0.053)\end{array}$ & $\begin{array}{l}1.000^{* * *} \\
(0.020)\end{array}$ & $\begin{array}{l}1.000^{* * *} \\
(0.038)\end{array}$ \\
\hline Additional controls & No & Yes & No & Yes & No & Yes & No & Yes \\
\hline Observations & 286 & 275 & 286 & 275 & 286 & 275 & 286 & 275 \\
\hline$R$-squared & 0.640 & 0.960 & 0.640 & 0.959 & 0.892 & 0.909 & 0.964 & 0.976 \\
\hline
\end{tabular}

Notes: See Table 3.

estimators. Given that these regressions basically rely on 26 cross-section observations, the reduced significance and the sensitivity when including the extensive range of control variables is not surprising. ${ }^{24}$

In columns 5-8 we report the results from the fixed effects vector decomposition models for the estimation of timeinvariant variables in panel data models with cross-section specific effects (Pluember and Troeger, 2007). ${ }^{25}$ Fixed effects vector decomposition relies on a 3-stage procedure in which a cross-section specific error $\left(e_{i}\right)$ net of time invariant factors is calculated. This procedure allows us to decompose cross-section effects into an explained (time-invariant explanatory variables $z$ ) and an unexplained part $\left(e_{i}\right)$. In the first stage a standard fixed effects model is estimated and estimated unit effects $\hat{u}_{i}$ are extracted. In the second stage the estimated unit effects $\hat{u}_{i}$ are regressed on the observed time-invariant variables $z$. Hence, the unit effects $\hat{u}_{i}$ are decomposed into an explained part $z$ and an unexplained part $e_{i}$, the residual. $e_{i}$ now contains unit specific unexplained variation. This unit effect $e_{i}$ is by construction no longer correlated with the time-invariant variables $z$. In the third stage a pooled OLS model including all explanatory variables $x$ from the first stage, time-invariant variables $z$ and the unexplained unit effect $e_{i}$ is estimated. Hence, this final stage decomposes observe and unobserved cross-section specific effects.

The findings of the previous regressions are confirmed in that auditors with a more extensive auditing mandate significantly reduce taxation and government expenditures. Note that the standard errors are extremely small for all covariates. This is due to the orthogonalization in the second stage, which technically increases efficiency but leads to overconfidence in the estimation.

\subsubsection{Alternative procedure to correct for within-group dependence: wild cluster bootstrap-t}

In this section we take into account that the standard errors might still suffer from downward bias since the standard method for correcting for within-group dependence is justified asymptotically and assumes that the number of clusters is large. Hence, when the number of clusters is small we might still over-reject the null hypothesis. The recent contribution by Cameron et al. (2008) proposes the wild cluster bootstrap-t procedure and shows that this method performs well even with as little as five clusters. ${ }^{26}$ We apply this procedure according to the three steps proposed in Appendix B of Cameron et al. (2008) and we base our implementation on the code used by these authors when replicating the Gruber and Poterba (1994) results. Similar to Cameron et al. (2008) we use Rademacher weights and perform 999 bootstrap replications.

Table 9 summarizes our main results when applying the wild cluster bootstrap-t method. We always present our basic specification only including the baseline controls, specifications controlling for time effects (if appropriate), and the specification including the full set of control variables.

As can be seen from the $p$-values of the wild cluster bootstrap-t procedure which are reported in brackets, our results remain statistically significant. An exception is the baseline specification of the expenditure regression (column 6). Similar to the results reported in Table 4, conventional levels of statistical significance are not achieved in this specification. Overall standard errors are somewhat higher than when using the common cluster-robust variance estimator. This result is in line

\footnotetext{
${ }^{24}$ It is noteworthy that even year-specific cross-section regressions from 1990 to 2000 reveal significant and comparable results. Exceptions are only the estimates for the years 1995 and 1996 for which the tax regressions produce similar coefficients but statistical significance is just not achieved (see Schelker, 2008).

${ }^{25}$ Thanks to an anonymous referee for suggesting this method.

${ }^{26}$ Thanks to an anonymous referee for pointing this out.
} 
Table 9

Robustness - Within-group Dependence: Wild Cluster Bootstrap-t.

\begin{tabular}{|c|c|c|c|c|c|c|c|c|}
\hline (Standard errors cluste & $\begin{array}{l}\text { by canton i } \\
\text { (1) }\end{array}$ & $\begin{array}{l}\text { arentheses) } \\
(2)\end{array}$ & $\begin{array}{l}\text {-values gene } \\
\text { (3) }\end{array}$ & $\begin{array}{l}\text { ed by wild cl } \\
\text { (4) }\end{array}$ & $\begin{array}{l}\text { ter bootstra } \\
(5)\end{array}$ & $\begin{array}{l}\text { in brackets] } \\
(6)\end{array}$ & (7) & (8) \\
\hline Dataset & Municipal & Municipal & Cantonal & Cantonal & Cantonal & Cantonal & Cantonal & Cantonal \\
\hline Dependent variable & Tax & Tax & Tax & Tax & Tax & Expenditure & Expenditure & Expenditure \\
\hline \multirow{2}{*}{$\begin{array}{l}\text { Estimation } \\
\text { method }\end{array}$} & WLS & WLS & Random & Random & Random & Random & Random & Random \\
\hline & & & Effects & Effects & Effects & Effects & Effects & Effects \\
\hline Original Table & 1 & 1 & 3 & 3 & 3 & 4 & 4 & 4 \\
\hline Regression & $(2)$ & $(7)$ & $(5)$ & $(7)$ & $(8)$ & $(5)$ & (7) & (8) \\
\hline \multirow[t]{2}{*}{ Auditor } & $-0.483^{* *}$ & $-0.435^{* * *}$ & $-11.358^{* * *}$ & $-11.920^{* * *}$ & $-7.003^{* * *}$ & -465.364 & $-392.356^{* * *}$ & $-668.243^{* *}$ \\
\hline & $(0.114)$ & $(0.087)$ & (3.693) & $(3.739)$ & $(3.463)$ & $(370.092)$ & $(213.404)$ & $(260.228)$ \\
\hline Wild cluster bootstrap- $t$ & {$[p=0.016]$} & {$[p=0.008]$} & {$[p=0.002]$} & {$[p=0.002]$} & {$[p=0.044]$} & {$[p=0.186]$} & {$[p=0.002]$} & {$[p=0.012]$} \\
\hline Base controls & yes & yes & yes & yes & yes & yes & yes & yes \\
\hline Full set of controls & no & yes & no & no & yes & no & no & yes \\
\hline Time effects & & & no & yes & no & no & yes & no \\
\hline Observations & 732 & 718 & 286 & 286 & 286 & 286 & 275 & 275 \\
\hline$R$-squared & 0.664 & 0.738 & 0.534 & 0.518 & 0.705 & 0.475 & 0.731 & 0.802 \\
\hline LM Breusch-Pagan & & & 726.25 & 746.11 & 293.10 & 1071 & 1068 & 312.7 \\
\hline
\end{tabular}

Further details see respective tables.

Notes: Significance level according to wild cluster bootstrap-t procedure:

${ }^{*} 0.05<p<0.1$.

*** $0.01<p<0.05$.

**** $p<0.01$.

with the findings presented by Cameron et al. (2008). Only when including time fixed effects in the panel specifications the $p$-value of the wild cluster bootstrap is lower compared to the standard cluster-robust variance estimates.

\subsubsection{Further evidence ${ }^{27}$}

As further robustness checks we also analyzed the influence of auditors on local and cantonal revenues. The patterns of the regression results for public revenues are roughly similar in terms of coefficient size and significance to the ones reported in Table 4 on the impact of auditors on expenditures. ${ }^{28}$

One concern could be that auditors just cater to the rich who prefer lower taxes. From the limited data we have, we do not find indications that this is actually the case, since auditors cannot decide on public policy, but can only consult citizens about the potential impact of policies. The available data contains information about the after-tax Gini-coefficients calculated for the fiscal year 1995/1996. We find a statistically significant negative effect of the auditor variable on the aftertax Gini-coefficient. This suggests that auditors are unlikely to particularly represent the interests of the rich. However, note that a strict test would require comparing pre- and after-tax Gini-coefficients.

Torgler (2005) drawing on our early work on auditors, empirically analyzes their impact on tax moral. The basic argument is that citizens are more willing to contribute to the local public good if they can better control the agent and if public goods provision is more effectively tailored to the preferences of the citizens. Using our auditor index he finds that more powerful auditors enhance tax moral. However, in contrast to our estimates on expenditures and taxes the effect is not robust to the inclusion of the extent of direct democratic instruments available to the citizens.

\subsection{Causality}

Causality is obviously a crucial issue. Our theoretical considerations suggest a relationship going from auditors to policy outcomes. However, one might come up with arguments suggesting reverse causation or that a third unobserved factor determines both aspects simultaneously. Certainly, institutions do evolve over time and insofar, they are partly endogenous.

In our case, it is difficult to argue for reverse causality, because the institutional design of auditing institutions was fairly stable over time. The second argument of simultaneity is more important for fiscal institutions. Since we can only draw inference from cross-sectional variation we cannot exclude unobserved time-invariant cross-section heterogeneity by estimating fixed effects models. However, we address this problem by including a large number of institutional control variables, measures of fiscal preferences as well as by formulating and testing differential hypotheses.

\footnotetext{
27 For regression results and a detailed summary and interpretation of further evidence see Schelker and Eichenberger (2008).

28 Alternative fiscal measures that come to mind are deficits and debt. However, our theory focuses on the size of government, since the full cost of projects are not fully internalized due to common pool interests that are under-represented. Hence, when estimating the effect of auditors on deficits (public debt data is not available) we do not find robust estimates.
} 
It is often argued that fiscal institutions are shaped by certain fiscal preferences that simultaneously determine policy outcome and institutional design. We addressed this issue by including measures for fiscal preferences and we did not find any evidence challenging our results (see Tables 1-4). Furthermore, we discussed a differential hypothesis derived from our theoretical considerations (Hypothesis 2 and Tables 5-7), which makes it less plausible that an unobserved factor is driving both institutions and outcomes simultaneously in such a subtle way. Naturally, we also tried to address the problem of causality econometrically by estimating instrumental variables. Typically, it is very difficult to find valid instruments for institutions. Even after substantial efforts we could not come up with entirely convincing instruments. Either the correlations with the potentially endogenous covariate were not strong enough or the exclusion restriction could not always be met convincingly. Therefore, we do not report the results in this paper. The estimated IV regressions indicate a slightly higher negative and significant effect of auditors on taxes and expenditures. The IV results can be found in the working paper version of this paper (Schelker and Eichenberger 2008).

Since, we cannot provide strong IV results the interpretation of our results has to be cautious. Nevertheless, there is strong evidence for robust correlations between auditors and fiscal outcomes, for which omitted factors such as the widely discussed fiscal preferences cannot account for. Moreover, in our understanding there is no straightforward theory or hypothesis suggesting a correlation between fiscal variables and auditors through the population channel (as in Hypothesis 2), which would account for our results and suggest reverse causality or simultaneity.

\section{Summary and conclusion}

Public auditing institutions are generally considered important, but so far there have not been many theoretical and empirical economic analyses. This contribution goes beyond the traditional view of public auditing institutions by not only stressing ex post audits, but also ex ante audits targeted at the budget draft and individual policy projects before the political decision is taken and the policy is implemented. In addition to ex post financial and performance audits, we argue that auditors can play an important role also during the policy making process. The information asymmetry between large common pool interests and small special interest groups leads to a regular overuse of common pool resources. The ex ante evaluations of the budget draft and individual projects by an independent auditor improve transparency and reduce this information asymmetry, which in turn decreases overspending of public resources.

In the empirical section we analyze the impact of auditors on fiscal variables, such as taxes and expenditures. We follow our theoretical hypotheses that predict lower tax rates and expenditures if auditors have a more extensive auditing mandate including ex post performance audits, ex ante audits of the budget draft and individual policy proposals. Furthermore, we have established that auditors should be more effective in large municipalities in which control and collective action problems are more pronounced than in smaller municipalities. We discover support for both theoretical hypotheses. We find a large negative economically and statistically significant influence on taxes and expenditures. Furthermore, auditors have a more important impact in larger than in smaller municipalities. We find robust results for different degrees of data aggregation as well as for changes in the empirical specifications. To establish causal relations we follow three different strategies: (1) we proxy our main source of potential endogeneity with new measures of fiscal preferences. (2) We test a differential hypothesis in which the main channels of endogeneity appear rather implausible. (3) We estimate instrumental variable models and find similar results in most specifications. However, as in many other studies it proved to be very difficult to find convincing instruments. The three different approaches confirm our previous results and indicate a robust relationship in which more powerful auditors reduce taxes and public expenditures. Hence, we suggest taking into account the potential role of auditors to reduce the asymmetric influence of special interests during the policymaking process. We propose to revise the traditional view on auditing institutions: the auditing mandate should be extended to include ex ante audits of the budget draft as well as policy proposals to reduce the information asymmetry between special and common pool interests in the fiscal policy process.

\section{Acknowledgments}

We would like to thank Jim Alt, Lars Feld, Bruno Frey, Jeff Frieden, Michael Funk, Gretchen Helmke, Roland Hodler, Gerald Hosp, Gehard Kirchgässner, Lorenz Kueng, Simon Loertscher, Friedrich Schneider, Andrei Shleifer, and David Stadelmann for helpful comments and discussions on various parts of this paper. We would also like to thank two anonymous referees as well as participants of various seminars and workshops at Harvard University, the Universities of Barcelona, Bern and Fribourg as well as participants of conferences such as the Annual Meeting of the International Society of New Institutional Economics, the Public Choice Society Meeting, the European Public Choice Society Meetings, and the Annual Conference of the European Economic Association for feedback and comments.

\section{Appendix}

See Tables A1-A4. 
Table A1

Construction of the auditor variables (finance commission index). Source: Schelker and Eichenberger (2003).

\begin{tabular}{|c|c|c|c|c|c|c|c|}
\hline Canton & $\begin{array}{l}\text { Individual } \\
\text { projects ex post }\end{array}$ & $\begin{array}{l}\text { Budget } \\
\text { proposal ex } \\
\text { ante }\end{array}$ & $\begin{array}{l}\text { Individual } \\
\text { projects }\end{array}$ & $\begin{array}{l}\text { Alternative } \\
\text { propositions }\end{array}$ & $\begin{array}{l}\text { Auditor (finance } \\
\text { commission index) }\end{array}$ & $\begin{array}{l}\text { Prevalence of } \\
\text { town meeting }\end{array}$ & $\begin{array}{l}\text { Auditor variable for } \\
\text { cantonal data }\end{array}$ \\
\hline Argovia & 1 & 1 & 0 & 1 & 3 & 0.78 & 2.34 \\
\hline $\begin{array}{l}\text { Appenzell } \\
\text { OR }\end{array}$ & 1 & 0 & 0 & 0 & 1 & 0.71 & 0.71 \\
\hline Appenzell IR & 1 & 0 & 0 & 0 & 1 & 1.00 & 1.00 \\
\hline $\begin{array}{l}\text { Basle- } \\
\text { Country }\end{array}$ & 1 & 1 & 0 & 1 & 3 & 0.70 & 2.10 \\
\hline Basle-Town & - & - & - & - & - & 0.00 & 0.00 \\
\hline Berne & 0 & 0 & 0 & 0 & 0 & 0.55 & 0.00 \\
\hline Fribourg & 1 & 1 & 1 & 1 & 4 & 0.63 & 2.52 \\
\hline Geneva & - & - & - & - & - & 0.00 & 0.00 \\
\hline Glarus & 1 & 0 & 0 & 0 & 1 & 1.00 & 1.00 \\
\hline Grisons & 1 & 1 & 1 & 0 & 3 & 0.58 & 1.74 \\
\hline Jura & 0 & 0 & 0 & 0 & 0 & 0.67 & 0.00 \\
\hline Lucerne & 1 & 1 & 0 & 0 & 2 & 0.61 & 1.22 \\
\hline Neuchâtel & - & - & - & - & - & 0.00 & 0.00 \\
\hline Nidwalden & 1 & 1 & 1 & 0 & 3 & 1.00 & 3.00 \\
\hline Obwalden & 0 & 0 & 0 & 0 & 0 & 1.00 & 0.00 \\
\hline Schaffhausen & 1 & 0 & 0 & 0 & 1 & 0.25 & 0.25 \\
\hline Schwyz & 1 & 1 & 1 & 0 & 3 & 1.00 & 3.00 \\
\hline Solothurn & 1 & 0 & 0 & 0 & 1 & 0.93 & 0.93 \\
\hline St. Gall & 1 & 0 & 0 & 0 & 1 & 0.79 & 0.79 \\
\hline Thurgovia & 0 & 0 & 0 & 0 & 0 & 0.79 & 0.00 \\
\hline Ticino & 0 & 1 & 1 & 1 & 3 & 0.04 & 0.12 \\
\hline Uri & 1 & 1 & 0 & 0 & 2 & 1.00 & 2.00 \\
\hline Vaud & 0 & 1 & 1 & 1 & 3 & 0.11 & 0.33 \\
\hline Valais & 0 & 0 & 0 & 0 & 0 & 0.84 & 0.00 \\
\hline Zug & 1 & 1 & 0 & 0 & 2 & 0.77 & 1.54 \\
\hline Zurich & 1 & 1 & 1 & 1 & 4 & 0.51 & 2.04 \\
\hline
\end{tabular}

a Share of population living in municipalities with town meetings.

Table A2

Description of municipal data for the year 1999

\begin{tabular}{|c|c|c|c|c|}
\hline Variable & Min-Max & $\begin{array}{l}\text { Sample mean } \\
\text { (standard } \\
\text { deviation) }\end{array}$ & Description & Source \\
\hline Average tax rate & $5.46-14.59$ & $10.92(1.73)$ & $\begin{array}{l}\text { Average tax rate on a natural person's annual income. } \\
\text { Income classes: CHF } 40-200 \text { thousand }\end{array}$ & $\begin{array}{l}\text { Swiss Federal Tax } \\
\text { Administration }\end{array}$ \\
\hline Auditor & $0-4$ & $1.28(1.52)$ & $\begin{array}{l}\text { Index capturing institutional design of the local auditor } \\
\text { (finance commission index) }\end{array}$ & $\begin{array}{l}\text { Schelker and Eichenberger } \\
\text { (2003) }\end{array}$ \\
\hline $\begin{array}{l}\text { Local direct } \\
\text { democracy }\end{array}$ & $0 / 1$ & $0.70(0.46)$ & $\begin{array}{l}\text { Dummy for local direct democracy: town meeting ( } 1 \text {; } \\
\text { parliament }(0) \text {. }\end{array}$ & Own representation \\
\hline $\begin{array}{r}\text { Cantonal direct } \\
\text { democracy } 1\end{array}$ & $1.75-5.69$ & $3.95(1.12)$ & $\begin{array}{l}\text { Cantonal direct democracy } 1 \text { : extent of direct democratic } \\
\text { instruments available to the citizens }\end{array}$ & Frey and Stutzer $(2000,2001)$ \\
\hline $\begin{array}{r}\text { Cantonal direct } \\
\text { democracy } 2\end{array}$ & $0 / 1$ & $0.52(0.50)$ & $\begin{array}{l}\text { Cantonal direct democracy } 2 \text { : dummy for existence of } \\
\text { mandatory financial referendum ( } 1 \text { if existing, } 0 \\
\text { otherwise) }\end{array}$ & Feld and Matsusaka (2003) \\
\hline Decentralization & $3.2-6.1$ & $4.86(0.61)$ & Decentralization: extent of local autonomy & Ladner (1994) \\
\hline Income & $0.842-75.020$ & $\begin{array}{l}25.111 \\
(7.346)\end{array}$ & $\begin{array}{l}\text { Average municipal real income per capita in } 1000 \text { CHF } \\
\text { (federal direct income tax statistics: Reineinkommen der } \\
\text { nat. Person) }\end{array}$ & Swiss Federal Statistical Office \\
\hline Population & $1138-336,822$ & $\begin{array}{l}7635.49 \\
(17413.60)\end{array}$ & Size of municipal population & Swiss Federal Statistical Office \\
\hline $\begin{array}{l}\text { Population } \\
\text { density }\end{array}$ & $0.15-108.99$ & $7.93(10.24)$ & Population density (population per $\mathrm{km}^{2}$ ) & Swiss Federal Statistical Office \\
\hline Foreigner & $0.01-0.56$ & $0.18(0.09)$ & Fraction of foreign municipal population & Swiss Federal Statistical Office \\
\hline Unemployment & $0.5-5.1$ & $2.55(0.97)$ & Cantonal unemployment rate & Swiss Federal Statistical Office \\
\hline Industrial area & $0.00-0.21$ & $0.02(0.02)$ & Industrial fraction of municipal surface & Swiss Federal Statistical Office \\
\hline $\begin{array}{l}\text { Agricultural } \\
\text { fraction }\end{array}$ & $0.00-0.81$ & $0.40(0.19)$ & Agricultural fraction of municipal surface & Swiss Federal Statistical Office \\
\hline $\begin{array}{l}\text { Mountainous } \\
\text { fraction }\end{array}$ & $0.00-0.43$ & $0.04(0.08)$ & Mountainous fraction of municipal surface & Swiss Federal Statistical Office \\
\hline Young & $0.21-0.47$ & $0.33(0.04)$ & Fraction of the young population $(0-24)$ in a canton & Swiss Federal Statistical Office \\
\hline Aged & $0.03-0.27$ & $0.13(0.04)$ & Fraction of the old population $\left(65^{+}\right)$in a canton & Swiss Federal Statistical Office \\
\hline $\begin{array}{l}\text { Social } \\
\text { democrats }\end{array}$ & $0-93.32$ & $21.20(10.49)$ & $\begin{array}{l}\text { Share of votes for social democratic party in } 1999 \text { national } \\
\text { elections }\end{array}$ & Swiss Federal Statistical Office \\
\hline Language & $0 / 1$ & $0.76(0.43)$ & Language: German (1); else (0) & Own representation \\
\hline
\end{tabular}


Table A3

Description of cantonal data for the period $1990-2000$.

\begin{tabular}{|c|c|c|c|c|}
\hline Variable & Min-Max & $\begin{array}{l}\text { Sample mean } \\
\text { (standard } \\
\text { deviation) }\end{array}$ & Description & Source \\
\hline Taxes & $54.8-155.8$ & $103.03(19.70)$ & $\begin{array}{l}\text { Average cantonal and municipal tax burden on a } \\
\text { natural person's annual income (measured by an } \\
\text { index with yearly mean 100) }\end{array}$ & $\begin{array}{l}\text { Swiss Federal Statistical } \\
\text { Office }\end{array}$ \\
\hline Expenditures & $7983.1-19738.2$ & $11652.60(2535.77)$ & $\begin{array}{l}\text { Aggregated local and cantonal government } \\
\text { expenditures per capita (in real CHF) }\end{array}$ & $\begin{array}{l}\text { Swiss Federal Finance } \\
\text { Administration }\end{array}$ \\
\hline Auditor & $0-3$ & $1.02(1.01)$ & $\begin{array}{l}\text { Index capturing institutional design of the local } \\
\text { audit office: product of finance commission index } \\
\text { and prevalence of town meetings per canton }\end{array}$ & $\begin{array}{l}\text { Schelker (2007) and } \\
\text { Schelker and Eichenberger } \\
\text { (2003) }\end{array}$ \\
\hline $\begin{array}{l}\text { Local direct } \\
\text { democracy }\end{array}$ & $0-1$ & $0.63(0.34)$ & $\begin{array}{l}\text { Fraction of population per canton living in } \\
\text { municipality with town meeting }\end{array}$ & $\begin{array}{l}\text { Schelker and Eichenberger } \\
\text { (2003) }\end{array}$ \\
\hline $\begin{array}{r}\text { Cantonal direct } \\
\text { democracy } 1\end{array}$ & $1.50-5.83$ & $4.28(1.20)$ & $\begin{array}{l}\text { Cantonal direct democracy } 1 \text { : extent of direct } \\
\text { democratic instruments available to the citizens }\end{array}$ & $\begin{array}{l}\text { Frey and Stutzer ( } 2000 \text {, } \\
2001) \text {, Schaltegger }\end{array}$ \\
\hline $\begin{array}{r}\text { Cantonal direct } \\
\text { democracy } 2\end{array}$ & $0 / 1$ & $0.67(0.47)$ & $\begin{array}{l}\text { Cantonal direct democracy } 2 \text { : existence if } \\
\text { mandatory financial referendum ( } 1 \text { if existing, } 0 \\
\text { otherwise) }\end{array}$ & Feld and Matsusaka (2003) \\
\hline Decentralization & $3.2-6.1$ & $4.99(0.77)$ & Decentralization: extent of local autonomy & Ladner (1994) \\
\hline Income & 28959.9-84,605 & $44,064.20(9996.11)$ & Cantonal real income per capita in $\mathrm{CHF}$ & $\begin{array}{l}\text { Swiss Federal Statistical } \\
\text { Office }\end{array}$ \\
\hline Population & $13,573-1,211,647$ & $270,004.2(277,656.2)$ & Size of cantonal population & $\begin{array}{l}\text { Swiss Federal Statistical } \\
\text { Office }\end{array}$ \\
\hline $\begin{array}{l}\text { Population } \\
\text { density }\end{array}$ & $0.24-53.25$ & $4.39(9.96)$ & Cantonal population density (population per $\mathrm{km}^{2}$ ) & $\begin{array}{l}\text { Swiss Federal Statistical } \\
\text { Office }\end{array}$ \\
\hline Unemployment & $0-7.8$ & $2.29(1.96)$ & Cantonal unemployment rate & $\begin{array}{l}\text { Swiss Federal Statistical } \\
\text { Office }\end{array}$ \\
\hline Young & $0.145-0.283$ & $0.225(0.025)$ & $\begin{array}{l}\text { Fraction of the young population }(0-18) \text { in a } \\
\text { canton }\end{array}$ & $\begin{array}{l}\text { Swiss Federal Statistical } \\
\text { Office }\end{array}$ \\
\hline Aged & $0.112-0.215$ & $0.151(0.020)$ & Fraction of the old population (65+) in a canton & $\begin{array}{l}\text { Swiss Federal Statistical } \\
\text { Office }\end{array}$ \\
\hline Foreigner & $0.061-0.380$ & $0.166(0.65)$ & Share of cantonal foreign population & $\begin{array}{l}\text { Swiss Federal Statistical } \\
\text { Office }\end{array}$ \\
\hline Topography & $0.00-37.57$ & $3.85(8.20)$ & $\begin{array}{l}\text { Index of topographical conditions as measured by } \\
\text { the index which is used for the new national fiscal } \\
\text { equalization scheme (the "topographischer } \\
\text { Lastenausgleichsindex des NFA"); increasing } \\
\text { values denote more difficult conditions }\end{array}$ & $\begin{array}{l}\text { Swiss Federal Finance } \\
\text { Administration }\end{array}$ \\
\hline
\end{tabular}

Table A4

Correlations of main variables.

\begin{tabular}{|c|c|c|c|c|c|c|c|}
\hline & Auditor & Local dir. democr. & Cant. dir. democr. 1 & Cant. dir. democr. 2 & Federalism & Income & Population \\
\hline \multicolumn{8}{|l|}{ Municipal dataset } \\
\hline Auditor & 1 & & & & & & \\
\hline Local direct democracy & 0.5143 & 1 & & & & & \\
\hline Cant. dir. democracy 1 (index) & 0.3935 & 0.3496 & 1 & & & & \\
\hline Cant. dir. dem. 2 (fin. referendum) & -0.6308 & -0.0637 & -0.3480 & 1 & & & \\
\hline Federalism & 0.2627 & 0.3021 & 0.4661 & -0.2606 & 1 & & \\
\hline Income & 0.4007 & 0.0185 & 0.0549 & -0.3535 & 0.1971 & 1 & \\
\hline Population & -0.1383 & -0.3126 & -0.0707 & -0.0502 & -0.0184 & 0.0307 & 1 \\
\hline \multicolumn{8}{|l|}{ Cantonal dataset } \\
\hline Auditor & 1 & & & & & & \\
\hline Local dir. dem. & 0.4826 & 1 & & & & & \\
\hline Cant. dir. dem. 1 (index) & 0.3975 & 0.7120 & 1 & & & & \\
\hline Cant. dir. dem. 2 (fin. referendum) & -0.0385 & 0.2590 & 0.2058 & 1 & & & \\
\hline Federalism & 0.0605 & 0.4121 & 0.6000 & 0.0686 & 1 & & \\
\hline Income & 0.2281 & -0.1814 & 0.0959 & -0.2678 & 0.2209 & 1 & \\
\hline Population & -0.0203 & -0.3000 & -0.3348 & -0.2095 & -0.2172 & 0.1300 & 1 \\
\hline
\end{tabular}

\section{References}

Acemoglu, Daron., 2003. Why not a political Coase theorem? Social conflict, commitment, and politics. Journal of Comparative Economics 31, 620-652. Alesina, Alberto, Perotti, Roberto, 1996. Fiscal discipline and the budget process. American Economic Review 86 (2), 401-407.

Alt, James E., Lassen, David Dreyer, 2006. Fiscal transparency, political parties, and debt in OECD countries. European Economic Review 50, $1403-1439$. Baqir, Reza, 2002. Districting and government overspending. Journal of Political Economy 110 (6), 1318-1354.

Bernoth, Kerstin, Wolff, Guntram B., 2008. Fool the markets? Creative accounting, fiscal transparency and sovereign risk premia. Scottish Journal of Political Economy 55 (4), 465-487. 
Besley, Timothy, 2006. Principled Agents? The Political Economy of Good Government. Oxford University Press.

Besley, Timothy, Case, Anne, 2003. Political institutions and policy choices: evidence from the United States. Journal of Economic Literature 41, 7-73.

Besley, Timothy, Coate, Stephen, 2003. Elected versus appointed regulators: theory and evidence. Journal of the European Economic Association 1 (5), 11761206.

Buchanan, James M., Tullock, Gordon, 1962. The calculus of consent: logical foundations of constitutional democracy. University of Michigan Press, Ann Arbor.

Cameron, Colin, Gelbach, Jonah B., Miller, Douglas L., 2008. Bootstrap-based improvements for inference with clustered errors. Review of Economics and Statistics 90 (3), 414-427.

Dewatripont, Mathias, Jewitt, Ian, Tirole, Jean, 1999. The economics of career concerns, part II: application to missions and accountability of government agencies. Review of Economic Studies 66, 199-217.

Ecoplan, 2004. Verteilung des Wohlstands in der Schweiz. Ecoplan, Berne.

Eichenberger, Reiner., 1994. The benefits of federalism and the risk of overcentralization. Kyklos 47, 403-420.

Eichenberger, Reiner, Schelker, Mark, 2007. Independent and competing agencies: an effective way to control government. Public Choice 130, 79-98.

Eichenberger, Reiner, Serna, Angel, 1996. Random errors, dirty information, and politics. Public Choice 86, $137-156$.

Feld, Lars P., Kirchgässner, Gebhard, 2001. The political economy of direct legislation: direct democracy and local decision-making. Economic Policy 16 (33), 331-367.

Feld, Lars P., Matsusaka, John G., 2003. Budget referendums and government spending: evidence from Swiss Cantons. Journal of Public Economics 87, 27032724.

Feld, Lars P., Kirchgässner, Gebhard, Schaltegger, Christoph A., 2003. Decentralized Taxation and the Size of Government, Evidence from Swiss Sub-Federal Governments. CESifo Working Paper No. 1087.

Feld, Lars P., Schaltegger, Christoph A., Schnellenbach, Jan, 2008. On government centralization and fiscal referendums. European Economic Review (52), 611-645.

Ferejohn, John, 1999. Accountability and authority: toward a theory of political accountability. In: Przeworski, Adam, Stokes, Susan C., Manin, Bertrand (Eds.), Democracy, Accountability, and Representation. Cambridge University Press, pp. 131-153.

Ferraz, Claudio, Finan, Frederico, 2008. Exposing corrupt politicians: the effect of Brazil's publicly released audits on electoral outcomes. Quarterly Journal of Economics 123 (2), 703-745.

Frey, Bruno S., 1994. Supreme auditing institutions: a politico-economic analysis. European Journal of Law and Economics 1, $169-176$.

Frey, Bruno S., Stutzer, Alois, 2000. Happiness, economy and institutions. Economic Journal 110, 918-938.

Frey, Bruno S., Stutzer, Alois, 2001. Happiness and Economics. How the Economy and Institutions Affect Human Well-Being. Princeton University Press, Princeton.

Funk, Patricia, Gathmann, Christina, 2005. Estimating the Effect of Direct Democracy on Policy Outcomes. Preferences Matter! Working Paper, Stockholm School of Economics.

Funk, Patricia, Gathmann, Christina, 2008. Does Direct Democracy Reduce the Size of Government? New Evidence from Historical Data, 1890-2000. Working Paper, Stanford University.

Grossman, Gene M., Helpman, Elhanan, 2001. Special Interest Politics. MIT Press, Cambridge, MA.

Gruber, Jonathan, Poterba, James, 1994. Tax incentives and the decision to purchase health insurance: evidence from the self-employed. Quarterly Journal of Economics 109 (3), 701-733.

Ladner, Andreas, 1994. Finanzkompetenzen der Gemeinden - ein Überblick über die Praxis. In: Eng, F., Glatthard, A., Koenig, B.H. (Eds.), Finanzföderalismus, Emissionszentrale der Schweizer Gemeinden. Bern, pp. 64-85.

Lohmann, Susanne., 1998. An information rationale for the power of special interests. American Political Science Review $92,809-827$.

Maskin, Eric., Tirole, Jean., 2004. The politician and the judge: accountability in government. American Economic Review 94 (4), $1034-1054$.

Megert, Franziska, 2006. Die Rechnungsprüfungskommissionen der Gemeinden des Kantons Zürich. Master Thesis, Center for Public Finance, University of Fribourg.

Meltzer, Allan H., Richard, Scott F., 1981. A rational theory of the size of government. Journal of Political Economy 89 (5), $914-927$.

Milesi-Ferretti, Gian Maria, 2004. Good, bad or ugly? On the effects of fiscal rules with creative accounting. Journal of Public Economics 88, $377-394$.

Milesi-Ferretti, Gian Maria, Perotti, Roberto, Rostagno, Massimo, 2001. Electoral systems and public spending. Quarterly Journal of Economics 117 (2), 609-657.

Moulton, Brent R., 1986. Random group effects and the precision of regressions estimates. Journal of Econometrics 32, $385-397$.

Mueller, Dennis C., 2003. Public Choice III. Cambridge University Press, Cambridge.

Olken, Benjamin A., 2007. Monitoring corruption: evidence from a field experiment in Indonesia. Journal of Political Economy 115 (2), 200-249.

Olson, Mancur, 1965. The Problem of Collective Action. Public Goods and the Theory of Groups. Harvard University Press.

Persson, Torsten, Tabellini, Guido, 2000. Political Economics: Explaining Economic Policy. MIT Press, Cambridge, MA.

Persson, Torsten, Tabellini, Guido, 2004. Constitutional rules and fiscal policy outcomes. American Economic Review 94 (1), 25-45

Persson, Torsten, Roland, Gérard, Tabellini, Guido, 1997. Separation of powers and political accountability. Quarterly Journal of Economics $112,1163-1202$.

Persson, Torsten, Roland, Gérard, Tabellini, Guido, 2000. Comparative politics and public finance. Journal of Political Economy 108 (6), $1121-1161$.

Pujol, Francesc, Weber, Luc, 2003. Are preferences for fiscal discipline endogenous? Public Choice 114, 421-444.

Pluember, Thomas, Troeger, Vera E., 2007. Efficient estimation of time-Invariant and rarely changing variables in finite sample panel analyses with unit fixed effects. Political Analysis 15, 124-139.

Schaltegger, Christoph A., 2001. Ist der Schweizer Föderalismus zu kleinräumig? Swiss Political Science Review 7, 1-18.

Schaltegger, Christoph A., Feld, Lars P., 2009. Do large cabinets favor large governments? Evidence on the fiscal commons problem for swiss cantons. Journal of Public Economics 93, 35-47.

Schelker, Mark, 2008. Making Auditors Effective: Theory, Evidence, Perspectives. Nomos, Baden-Baden.

Schelker, Mark, 2010. The influence of auditor term length and term limits on US state general obligation bond ratings. Public Choice, forthcoming.

Schelker, Mark, Eichenberger, Reiner, 2003. Starke Rechnungsprüfungskommissionen: Wichtiger als direkte Demokratie und Föderalismus? Ein erster Blick auf die Daten. Swiss Journal of Economics and Statistics 139 (3), 351-373.

Schelker, Mark, Eichenberger, Reiner, 2008. Rethinking Public Auditing Institutions: Empirical Evidence from Swiss Municipalities. CREMA Working Paper $2008,6$.

Shepsle, Kenneth A., Weingast, Barry R., 1994. Positive theories of congressional institutions. Legislative Studies Quarterly 19 (2), $149-179$.

Stutzer, Alois, 1999. Demokratieindizes für die Kantone der Schweiz. IEW. Working Paper No. 23, Institute for Empirical Research in Economics, University of Zurich.

Torgler, Benno, 2005. A knight without a sword? The effects of audit courts on tax morale in Switzerland. Journal of Institutional and Theoretical Economics 161 (4), 735-760.

von Hagen, Jürgen, 1992. Budgeting Procedures and Fiscal Performance in the European Community. EEC Economic Papers, 96.

von Hagen, Jürgen, Harden, Ian J., 1995. Budget processes and commitment to fiscal discipline. European Economic Review 39, 771-779.

Wallack, Jessica S., 2007. Picking Numbers: The Highs and Lows of Revenue Estimating. Working Paper, UC, San Diego.

Weingast, Barry R., Marshall, William J., 1988. The industrial organization of congress; or, why legislatures, like firms, are not organized as markets. Journal of Political Economy 96, 132-163.

Weingast, Barry.R., Shepsle, Kenneth.A., Johnson, Christopher., 1981. The political economy of benefits and costs: a neoclassical approach to distributive politics. Journal of Political Economy 89 (4), 642-664.

Wooldridge, Jeffrey M., 2002. Econometric Analysis of Cross Section and Panel Data. MIT Press, Cambridge, USA. 